\title{
Modeling Pinus pinaster forest structure after a large wildfire using remote sensing data at high spatial resolution
}

\author{
José Manuel Fernández-Guisuraga *, Susana Suárez-Seoane, Leonor Calvo \\ Area of Ecology. Department of Biodiversity and Environmental Management, Faculty of Biological and Environmental Sciences, University of León, 24071 León, Spain
}

\section{A R T I C LE INFO}

\section{Keywords:}

Image texture

Pine population

Post-fire decision-making

Spectral index

Understory community

WorldView-2

\begin{abstract}
A B S T R A C T
In the Mediterranean Basin, wildland fires are major drivers of forest ecosystem dynamics. In the current context of global change, these fires are becoming more severe and recurrent because of climatic conditions, land use changes and invasive species. In areas affected by mega-fires (burned area $>10,000 \mathrm{ha}$ ), the patterns of regeneration may be heterogeneous due to local variations in fire regime, community composition and environmental features. The goal of this study was to analyze the post-fire structure of both Pinus pinaster Aiton. seedlings population and understory community in a Mediterranean fire-prone ecosystem at short-term by means of high spatial resolution satellite imagery within the perimeter of a full stand replacing mega-fire that burned around 12,000 ha of a Pinus pinaster forest in NW Spain. We established 234 field plots of $2 \times 2$ meters to cover four recurrence-severity scenarios. In each plot, we sampled 15 vegetation structural variables at both pine seedlings population and understory community levels. From the WorldView-2 satellite imagery, we obtained three sets of spectral variables (reflectance, spectral indices and image textures) that were used as predictors of vegetation recovery in generalized linear models. At population level, the number and cover of pine seedlings were successfully modeled with spectral indices and textural information (normalized root mean square error of $16 \%$ and $17 \%$, respectively). At understory community level, woody species cover was correlated with first order textures (normalized root mean square error of 9\%). Other understory structure variables (height and richness of woody species, percentage of bare soil, necromass and leaves) were predicted with an error lower than $20 \%$. The predictive capacity of the models was similar for all recurrence-severity scenarios. Our results highlight the usefulness of spectral indices and textural data at high spatial resolution in the analysis of post-fire recovery in large and heterogeneous burnt areas. Given the accuracy and predictive capacity of the models obtained in this study, high spatial resolution satellite imagery together with field data provide useful information in post-fire decision making in fire prone ecosystems.
\end{abstract}

\section{Introduction}

In the Mediterranean Basin, forest fires are major drivers of ecosystem productivity, composition and dynamics (Lozano et al., 2008; Sagra et al., 2018). In this region, forest fires are increasingly larger and are becoming more severe and recurrent, mainly due to climatic factors and land use changes (Chuvieco et al., 2010; Moreira et al., 2011; Álvarez et al., 2012; Lecina-Diaz et al., 2014; Quintano et al., 2015), but also to alien species introduction (Pausas and Keeley, 2014). Furthermore, large forest fires imply a loss of the ecosystem services provided by forests (Calvo et al., 2015), which finally may affect human health (Van Drooge et al., 2016).

\footnotetext{
* Corresponding author.

Email address: jofeg@unileon.es (J.M. Fernández-Guisuraga)
}

In Mediterranean fire-prone ecosystems, pine populations not only supply provisioning ecosystems services like timber (Leone and Lovreglio, 2004), resin (Soliño et al., 2018) or mushrooms (Taye et al., 2016), but also regulating services such as soil protection, biodiversity support and cultural ecosystem services such as recreational benefits (Leone and Lovreglio, 2004). On the other hand, the understory community also plays a key role in the provision of regulating ecosystem services in fire-prone pine ecosystems (Gonzalez et al., 2013) such as protection against soil erosion processes (Shakesby, 2011; Vieira et al., 2018). Therefore, rapid and effective post-fire regeneration evaluation is considered key for both the dominant tree species population and the understory community of these ecosystems (Fernández-Guisuraga et al., 2019) in order to recover their services supply (Leverkus et al., 2018; Schmeer et al., 2018). The evaluation of other post-fire variables 
such as the dead plant material cover (i.e., coarse and fine woody debris), is also of crucial importance for land management decision-making (Pesonen et al., 2008; Joyce et al., 2019). Dead plant material has a key role in the probability of occurrence of a new fire in a previously burned area (Sullivan et al., 2018) but, on the other hand, dead plant material increase rain interception following fire and behave as a sediment trap (Slesak et al., 2015).

Nevertheless, fire effects and vegetation recovery are not homogeneous across the landscape, due to spatial variations in fire regime parameters, species composition and environmental factors (Beaty and Taylor, 2001). Fire severity and recurrence are the fire regime parameters that most affect post-fire regeneration (González-De Vega et al., 2016; Tessler et al., 2016; Taboada et al., 2017; Fernández-García et al., 2018a). Thus, their explicit consideration in the assessment of spatial variations in post-fire regeneration is of vital importance for planning strategies of ecosystem restoration in areas affected by large fires (Ruíz-Gallardo et al., 2004; Moreira et al., 2009; Solans-Vila and Barbosa, 2010).

Because of the increase in the number of large forest fires, post-fire regeneration patterns in fire-prone pine ecosystems are increasingly heterogeneous (Fernández-García et al., 2018a), so that using exclusively field-work monitoring is unfeasible (Chuvieco and Kasischke, 2007). In this sense, remote sensing techniques (RST) are recognized as indispensable tools to evaluate vegetation regeneration patterns after fire, particularly across large areas (Lozano et al., 2012; Veraverbeke et al., 2012; Fernández-Manso et al., 2016). However, the application of RST is still a challenge in the case of heterogeneous mega-fires (burned area > 10,000 ha; Stephens et al., 2014) with high variation in fire regime parameters (Schoennagel et al., 2008; Chu et al., 2016).

Among the products derived from satellite imagery, spectral indices are the most frequently employed in post-fire vegetation regeneration analysis (Marchetti et al., 1995; Diaz-Delgado et al., 2003; Clemente et al., 2009; Cuevas-Gonzalez et al., 2009; Lozano et al., 2010; Solans-Vila and Barbosa, 2010; Lozano et al., 2012; Veraverbeke et al., 2012; Chu et al., 2016). Other studies, such as that conducted by Pleniou and Koutsias (2013), have focused on the evaluation of reflectance bands as predictors of post-fire regeneration, instead of grouping the reflectance values into spectral indices. Additionally, some authors propose the use of satellite imagery texture analysis as an indicator of vegetation structural parameters allowing for quantifying spatial variability within a defined area (Kayitakire et al., 2006; Song and Dickinson, 2008; Eckert, 2012; Viedma et al., 2012; Wood et al., 2012; Gu et al., 2013; Bastin et al., 2014; Pu and Cheng, 2015). Texture analysis is particularly relevant with respect to other products derived from satellite imagery in areas of high heterogeneity in ground cover, since visible structures are not only related to discrete values of image pixels, but also to the spatial variation of these values between adjacent pixels (Gu et al., 2013).

Despite the increasing use of satellite products in post-fire recovery analysis, most of those studies are constrained by coarse resolution sensors to characterize post-fire environments with a high spatial heterogeneity (Meng et al., 2018). In this regard, the development of high spatial resolution satellite imagery, such as QuickBird or WorldView, provides an improved performance in the monitoring of vegetation structure in heterogeneous post-fire landscapes (Viedma et al., 2012; Jung et al., 2013; Chu et al., 2016; McKenna et al., 2018; Meng et al., 2018; Fernández-Guisuraga et al., 2019). However, to our knowledge, there are no studies evaluating the post-fire forest structure both at the dominant tree species population and the shrub community levels by means of high spatial resolution multispectral imagery alone (i.e. without the combined use of optical satellite imagery and active sensors), under the influence of the fire regime parameters and a high spatial fine-scale heterogeneity. This approach could have broad scientific implications for land management decision-making in Mediterranean fire- prone pine ecosystems since it is essential to separate the dominant tree species recovery and the understory recovery (García-Morote et al., 2017; Meng et al., 2018).

The main goal of this study was to analyze the Pinus pinaster Aiton. population and understory community structure in a Mediterranean fire-prone ecosystem after the occurrence of a stand replacing mega-fire, by means of high spatial resolution satellite imagery and an extensive field sampling campaign. Specifically, we try to: (1) Identify the vegetation structure variables that best correlate with spectral information under different scenarios of fire recurrence and severity, at the level of both the dominant tree species population and the understory community. (2) Determine the reflectance bands, spectral indices and textural features derived from WorldView-2 multispectral satellite imagery that best explain post-fire regeneration, which would therefore constitute a useful management tool in large and heterogeneous burned areas. We expect that within the perimeter of a stand replacing mega-fire where salvage logging was conducted following fire, the recovery models of the Pinus pinaster population will perform better in scenarios of low fire recurrence and severity. The pine seedling recruitment on these scenarios would be significant due to the massive seed storage in the canopy seed bank during the previous fire-free period (Tapias et al., 2004; Calvo et al., 2008; Calvo et al., 2016). Moreover, obligate seeder shrubs with a slow recovery rate are promoted under low fire recurrence scenarios and enhance seedling recruitment through facilitative interactions (Pausas and Vallejo, 1999; Taboada et al., 2017). In contrast, recurrent fires with short return interval will favor resprouter shrubs with a fast post-fire recovery rate (Calvo et al., 2012; Taboada et al., 2018), turning facilitative interactions into competitive ones (Taboada et al., 2017). Therefore, under fire regime scenarios with a high pine recruitment, the seedlings reflectance contribution would presumably be large enough so that their spectral response can be detected with the presence of surrounding vegetation. Furthermore, we expect the advantage of texture products, over reflectance values or spectral indices, in post-fire regeneration modeling under high spatial and fire regime heterogeneity (Gu et al., 2013) within the fire perimeter because the textural features allow for quantifying spatial relationships in reflectance values $(\mathrm{Pu}$ and Cheng, 2015).

The flowchart of this study is schematized in Fig. 1.

\section{Materials and methods}

\subsection{Study area. Definition of different scenarios of recurrence and severity}

The study area (Fig. 2) is located in Sierra del Teleno (NW Spain), within the perimeter of a full stand replacing mega-fire (11,602 ha) that occurred in August 2012 and affected a forest dominated by Pinus pinaster. The burned area sites at an average altitude of 1063 m.a.s.l. and is relief is typically Appalachian, with quartzite banks outcropping in the peaks forming prominent crests. The north of the area is made of wide valleys with moderate slopes, while the southernmost zone is mainly composed of sedimentary plains and terraces. This is an Atlantic-Mediterranean transition area, with a mean annual precipitation of $650 \mathrm{~mm}$, a mean annual temperature of $10^{\circ} \mathrm{C}$ and less than two months of summer drought. The soils are predominantly acidic ( $\mathrm{pH}$ 4.5-5.5), with sandy texture, being clay soils relegated to the quaternary deposits (Santamaría, 2015). Forests dominated by Pinus pinaster typically covered the quartzite slopes and tertiary soils of the surrounding plains and are particularly subject to the occurrence of large forest fires (Calvo et al., 2008). Therefore, the population of Pinus pinaster in this region shows adaptive characteristics to the prevailing fire regime, such as higher production of serotinous cones, thicker bark and earlier flowering age than other Spanish populations (Tapias et al., 2004; Alvarez et al., 2007). Quercus pyrenaica Willd. stands, more resistant to forest fires, are present in valley bottoms with deeper soils 

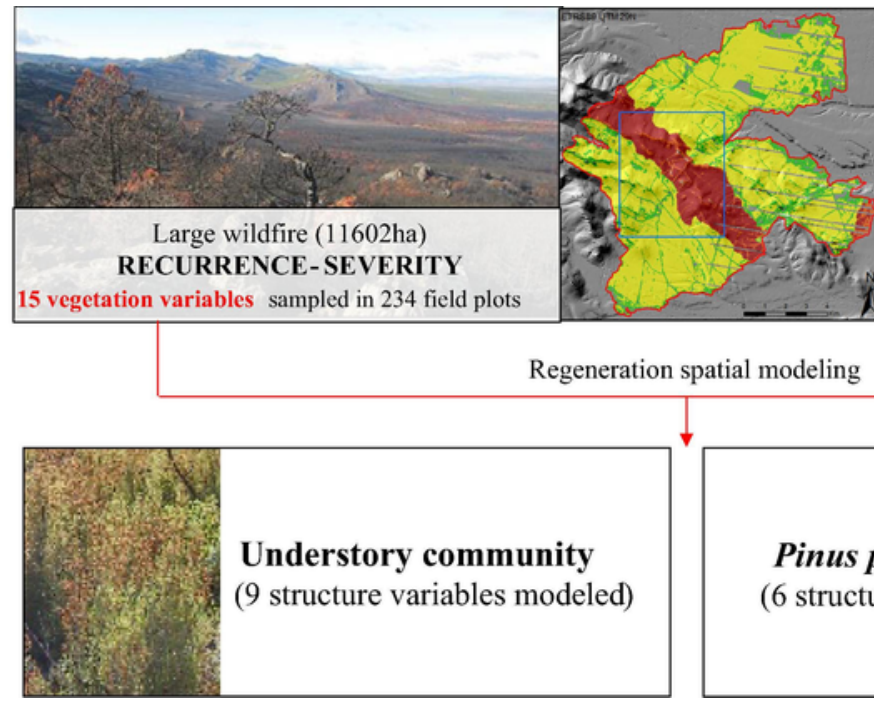

Fig. 1. Conceptual framework of the present study.
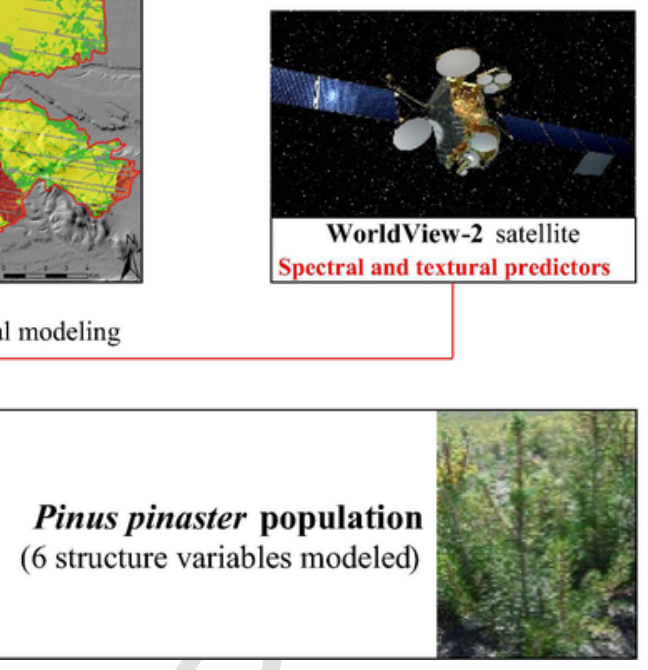

(Santamaría, 2015). The pine canopy was totally consumed by fire and the burned stands were salvaged logged in the two years immediately after the fire (Taboada et al., 2017; Taboada et al., 2018). Vegetation following fire mainly consists of Pinus pinaster regeneration stands in a seedling growth stage, being the understory plant community dominated by species such as Halimium lasianthum subsp. alyssoides (Lam.) Greuter, Pterospartum tridentatum (L.) Willk. and Erica australis L. (Calvo et al., 2008). Three years after the fire, the mean pine density in the study area was $2.25 \pm 0.15$ seedlings $/ \mathrm{m}^{2}$, the mean percent cover of pine seedlings per square meter was $4.30 \pm 0.26$ and their mean height was $22.71 \mathrm{~cm} \pm 0.71$ (Fernández-García et al., 2019).

Before the fire of 2012, the area had suffered another large fire in 1998 of around 3000 ha. Therefore, within the perimeter of the 2012 fire, we defined two fire recurrence scenarios: low recurrence (one fire in the last 15 years) and high recurrence (two fires in the last 15 years). Three months after the wildfire, we estimated the burn severity through the CBI (Composite Burn Index; Key and Benson, 2006) over 54 field plots of $30 \times 30 \mathrm{~m}$ randomly distributed using the protocol described in Fernández-García et al. (2018b). Additionally, the dNBR (differenced Normalized Burn Ratio) index (Key, 2006) was derived from Landsat pre-fire and post-fire images (September 20th, 2011 - September 6th, 2012). We established two severity scenarios within the perimeter of the fire of 2012 based on a dNBR threshold computed from the CBI (Miller and Thode, 2007; Quintano et al., 2015): low severity ( $\mathrm{dNBR} \leq 573$ ) and high severity $(\mathrm{dNBR}>573)$. Overlaying the recurrence and severity classes, we identified four recurrence-severity scenarios (low recurrence-low severity, low recurrence-high severity, high recurrence-low severity and high recurrence-high severity) (Fig. 2) to subsequently model post-fire regeneration with regard to the fire regime. Within the fire perimeter, we selected a 3000 ha study framework where the four scenarios of recurrence and severity were represented (Fig. 2) to collect field data for further model calibration and validation.

\subsection{Field data}

In summer of 2015, a set of 234 plots of $2 \times 2 \mathrm{~m}$ (resolution of WorldView-2) were randomly established in the field. The number of plots for each recurrence-severity scenario was proportional to the relative area occupied by each scenario within the fire perimeter (Table 1). The center of each plot was georeferenced by a sub-meter accuracy
GPS (Spectra Precision MobileMapper 20) in post-processing mode. The guaranteed accuracy after post-processing the coordinates was greater than $0.4 \mathrm{~m}$. Within each plot, we measured 15 regeneration structure variables of both the population of the dominant tree species (Pinus pinaster) and the understory community with a great potential in post-fire management decision-making (Table 2). All cover variables were estimated using the methodology of visual percentage cover (Calvo et al., 2008).

The values of the predictors were extracted from the pixels of WorldView- 2 image matching the $2 \times 2 \mathrm{~m}$ plots where field measurements were made. $66 \%$ of the experimental plots were used to calibrate the regeneration models, while the remaining $33 \%$ were used for validation (Table 1).

\subsection{WorldView-2 image data}

The WorldView-2 image was acquired on 16th of June 2015 at 10:34:02 UTC, with a cloud cover of $8.1 \%$. Sensors on-board WorldView-2 capture data in 11-bit format over a panchromatic (Pan, $450-800 \mathrm{~nm}$ ) and eight multispectral bands (MS, 400-1040 nm), with a spatial resolution of $0.5 \mathrm{~m}$ and $2.0 \mathrm{~m}$, respectively. This satellite image was selected due to its high spatial resolution, presumably able to discriminate between spatial structures given the scale of variability observed in the field. Furthermore, WorldView-2 is the first satellite to offer eight multispectral bands on the visible and infrared region of the spectrum (Ni et al., 2015).

\subsubsection{Image processing}

The image was orthorectified to subpixel accuracy (root mean square error $=0.58 \mathrm{~m}$ ) using rational polynomial coefficients provided with the image, a digital surface model with a resolution of $0.5 \mathrm{~m}$ and ground control points taken in the field. The radiometric calibration of the image to apparent surface reflectance was conducted by the atmospheric correction algorithm FLAASH, the acronym for Fast Line-of-sight Atmospheric Analysis of Spectral Hypercubes (Vermote et al., 1997; Adler-Golden et al., 1999; Berk et al., 1999; Matthew et al., 2003). Visibility, column water vapor amount and some ancillary data for atmospheric correction of the scene were obtained from the image metadata and from the State Meteorology Agency of Spain (AEMET). The workflow of the image processing is shown in Fig. 3. 


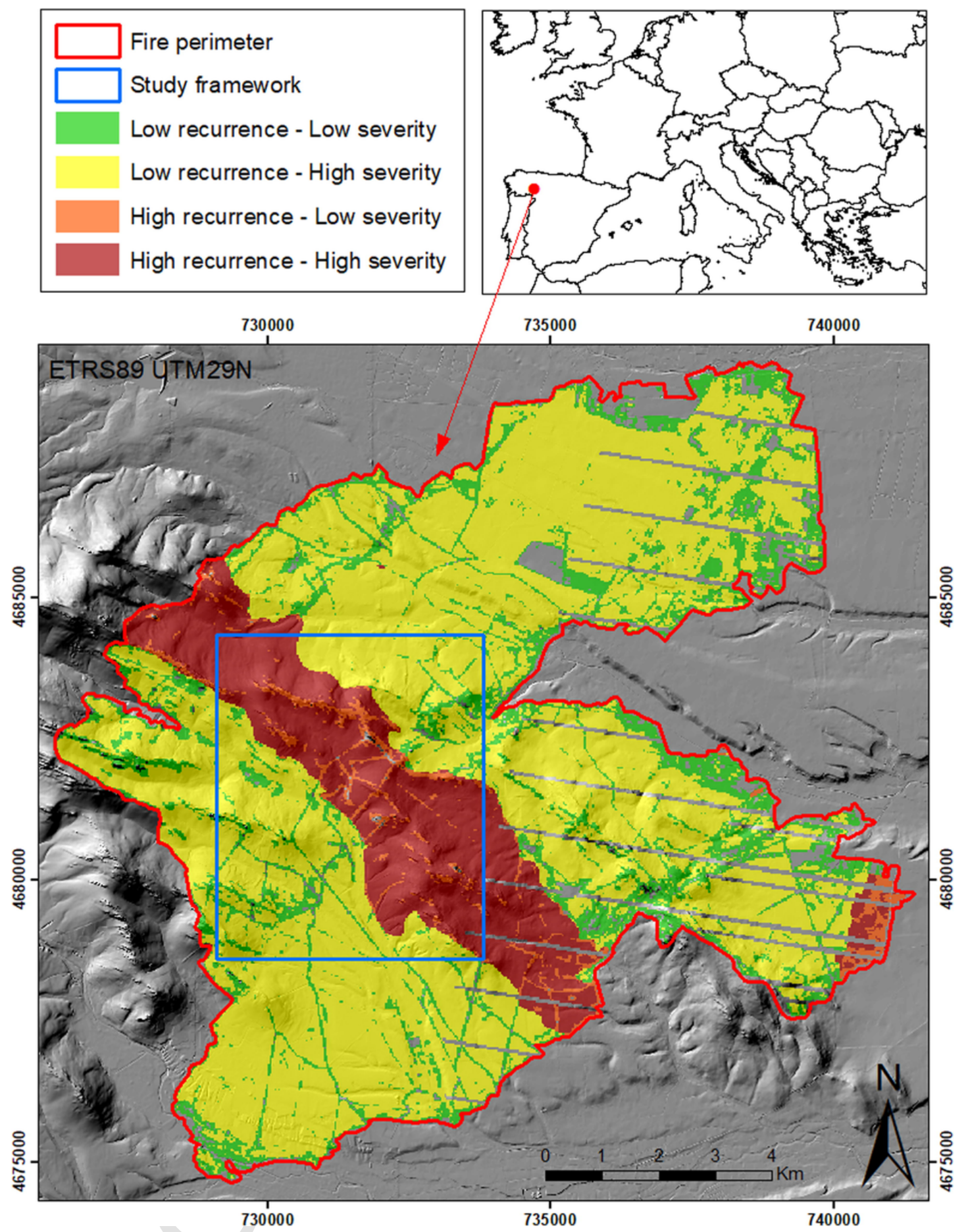

Fig. 2. Study framework within the perimeter of the Sierra del Teleno mega-fire which occurred in 2012, and the considered recurrence-severity scenarios.

2.3.2. Spectral predictors: Reflectance values, spectral indices and image textures

Three types of products were obtained from the WorldView-2 processed image to be used as predictors of vegetation recovery: (1) surface reflectance values, (2) spectral indices and (3) first and second order textures.

We accounted for the reflectance values of the eight bands of the imagery: 1-coastal blue (400-450 nm), 2-blue (450-510 nm), 3-green (510-580 nm), 4-yellow (585-625 nm), 5-red (630-690 nm), 6-red edge (705-745), 7-NIR1 (770-895 nm) and 8-NIR2 (860-1040 nm).
A total amount of 27 spectral indices were calculated from the apparent surface reflectance image and clustered into three groups: indices related to leaf pigments, detection indices of burned areas and soil and plant health indices (Table 3). These three sets of spectral indices are expected to account for the structure of the Pinus pinaster population and understory community during the first successional stages after the fire.

For each of the eight bands of WorldView-2 reflectance image, we calculated five first order (1rd) textures (occurrence statistic measurements: data range, mean, variance, entropy and skewness) and eight second order (2rd) textures (co-occurrence statistic measurements: 
Table 1

Number of experimental plots used for model calibration and validation across recurrence-severity scenarios.

\begin{tabular}{lllll}
\hline $\begin{array}{l}\text { Recurrence- } \\
\text { Severity } \\
\text { scenarios }\end{array}$ & $\begin{array}{l}\text { Low } \\
\text { recurrence \& } \\
\text { low severity }\end{array}$ & $\begin{array}{l}\text { Low } \\
\text { recurrence \& } \\
\text { high severity }\end{array}$ & $\begin{array}{l}\text { High } \\
\text { recurrence \& } \\
\text { low severity }\end{array}$ & $\begin{array}{l}\text { High } \\
\text { recurrence \& } \\
\text { high severity }\end{array}$ \\
\hline $\begin{array}{c}\text { Model } \\
\text { calibration } \\
\text { Model } \\
\text { validation }\end{array}$ & 24 & 60 & 24 & 48 \\
Total plots & 36 & 30 & 12 & 24 \\
\hline
\end{tabular}

Table 2

Field regeneration variables measured in $2 \times 2 \mathrm{~m}$ plots.

\begin{tabular}{|c|c|c|c|}
\hline Category & Variable & Code & $\begin{array}{l}\text { Unit of } \\
\text { measurement }\end{array}$ \\
\hline \multirow{6}{*}{$\begin{array}{r}\text { Pinus pinaster } \\
\text { population }\end{array}$} & No. of living seedlings & Pn & number \\
\hline & No. of dead seedlings & $\mathrm{dPn}$ & number \\
\hline & Average height of living seedlings & $\mathrm{Ph}$ & $\mathrm{cm}$ \\
\hline & $\begin{array}{l}\text { Maximum height of living } \\
\text { seedlings }\end{array}$ & Pmaxh & $\mathrm{cm}$ \\
\hline & $\begin{array}{l}\text { Minimum height of living } \\
\text { seedlings }\end{array}$ & Pminh & $\mathrm{cm}$ \\
\hline & Cover of seedlings & Pcov & $\%$ \\
\hline \multirow{9}{*}{$\begin{array}{l}\text { Understory } \\
\text { community }\end{array}$} & Cover of woody species & Wcov & $\%$ \\
\hline & $\begin{array}{l}\text { Maximum height of woody } \\
\text { species }\end{array}$ & Wmaxh & $\mathrm{cm}$ \\
\hline & Richness of woody species & Wrich & number \\
\hline & Cover of herbaceous species & Hcov & $\%$ \\
\hline & Richness of herbaceous species & Hrich & number \\
\hline & $\begin{array}{l}\text { Cover of leaves and thin branches } \\
\text { less than } 2 \mathrm{~cm}\end{array}$ & Lcov & $\%$ \\
\hline & $\begin{array}{l}\text { Cover of lying necromass greater } \\
\text { than } 2 \mathrm{~cm}\end{array}$ & Ncov & $\%$ \\
\hline & Cover of stones & St & $\%$ \\
\hline & Percentage of bare soil & S & $\%$ \\
\hline
\end{tabular}

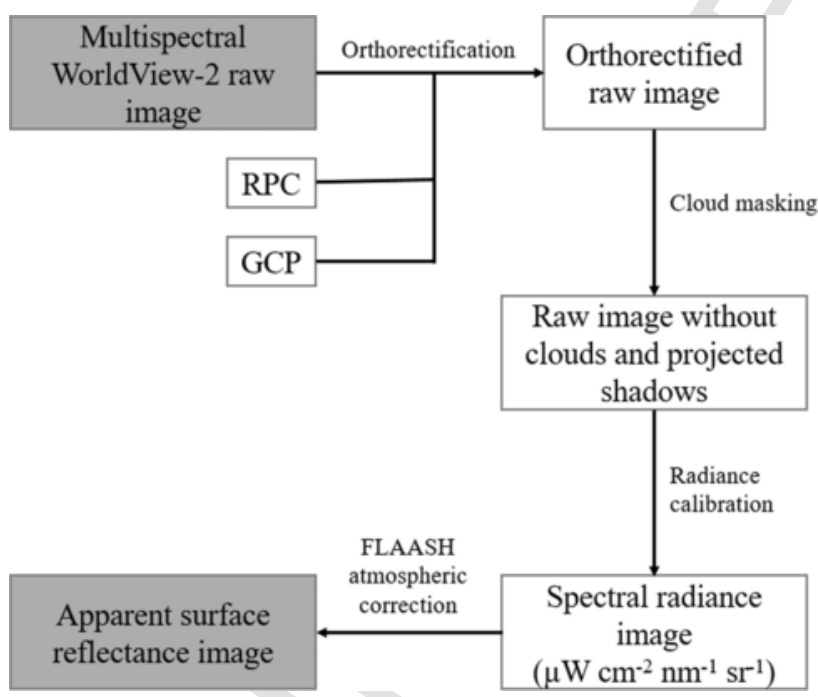

Fig. 3. Workflow of WorldView-2 image processing (RPC = rational polynomial coefficients; GCP = ground control points).

mean, variance homogeneity, contrast, dissimilarity, entropy, angular second moment and correlation) (Table 4). First order texture measurements are statistics calculated from the original pixel values in a moving window. The second order texture measurements are calculated using the Gray Level Co-Occurrence Matrix (GLCM), which describes the probability that the values of each pair of pixels concur in a given di-
Table 3

Spectral indices used in this study derived from WorldView-2 reflectance bands (B1-B8).

\begin{tabular}{|c|c|c|}
\hline Index & Formula & Reference \\
\hline \multicolumn{3}{|l|}{ Leaf pigments } \\
\hline $\begin{array}{l}\text { Anthocyanin } \\
\text { Reflectance Index } \\
2 \text { (ARI) }\end{array}$ & $\mathrm{B} 7[(1 / \mathrm{B} 3)-(1 / \mathrm{B} 6)]$ & $\begin{array}{l}\text { Gitelson et } \\
\text { al. (2001) }\end{array}$ \\
\hline $\begin{array}{l}\text { Carotenoid } \\
\text { Reflectance Index } \\
\text { (CRI) }\end{array}$ & $(1 / \mathrm{B} 3)-(1 / \mathrm{B} 6)$ & $\begin{array}{l}\text { Gitelson et } \\
\text { al. (2002a) }\end{array}$ \\
\hline $\begin{array}{l}\text { Modified } \\
\text { Chlorophyll } \\
\text { Absorption Ratio } \\
\text { Index (MCARI) }\end{array}$ & [(B6-B5)-0.2(B6-B3)](B6/B5) & $\begin{array}{l}\text { Daughtry } \\
\text { et al. } \\
(2000)\end{array}$ \\
\hline $\begin{array}{l}\text { Plant Senescence } \\
\text { Reflectance Index } \\
\text { (PSRI) }\end{array}$ & (B5-B3)/B6 & $\begin{array}{l}\text { Merzlyak } \\
\text { et al. } \\
\text { (1999) }\end{array}$ \\
\hline $\begin{array}{l}\text { Structure Intensitive } \\
\text { Pigment Index } \\
\text { (SIPI) }\end{array}$ & $(\mathrm{B} 7-\mathrm{B} 1) /(\mathrm{B} 7-\mathrm{B} 5)$ & $\begin{array}{l}\text { Penuelas et } \\
\text { al. (1995) }\end{array}$ \\
\hline $\begin{array}{l}\text { Transformed } \\
\text { Chlorophyll } \\
\text { Absorption } \\
\text { Reflectance Index } \\
\text { (TCARI) }\end{array}$ & $3[(\mathrm{~B} 6-\mathrm{B} 5)-0.2(\mathrm{~B} 6-\mathrm{B} 3)(\mathrm{B} 6 / \mathrm{B} 5)]$ & $\begin{array}{l}\text { Haboudane } \\
\text { et al. } \\
\text { (2004) }\end{array}$ \\
\hline \multicolumn{3}{|c|}{ Detection of burned areas and soil } \\
\hline $\begin{array}{l}\text { Burnt Area Index } \\
\text { (BAI) }\end{array}$ & $1 /\left[(0.1-\mathrm{B} 5)^{2}+(0.06-\mathrm{B} 8)^{2}\right]$ & $\begin{array}{l}\text { Chuvieco } \\
\text { et al. } \\
(2002)\end{array}$ \\
\hline $\begin{array}{l}\text { WorldView Soil } \\
\text { Index (WSI) }\end{array}$ & $(\mathrm{B} 3-\mathrm{B} 4) /(\mathrm{B} 3+\mathrm{B} 4)$ & $\begin{array}{l}\text { Wolf } \\
(2010)\end{array}$ \\
\hline \multicolumn{3}{|l|}{ Plant health } \\
\hline $\begin{array}{l}\text { Atmospherically } \\
\text { Resistant } \\
\text { Vegetation Index } \\
\text { (ARVI) }\end{array}$ & $(\mathrm{B} 7-2 \mathrm{~B} 5+\mathrm{B} 2) /(\mathrm{B} 7+2 \mathrm{~B} 5-\mathrm{B} 2)$ & $\begin{array}{l}\text { Kaufman } \\
\text { and Tanre } \\
(1992)\end{array}$ \\
\hline $\begin{array}{l}\text { Difference } \\
\text { Vegetation Index } \\
\text { (DVI) }\end{array}$ & B7-B5 & $\begin{array}{l}\text { Tucker } \\
\text { (1979) }\end{array}$ \\
\hline $\begin{array}{l}\text { Far Red to Red } \\
\text { Index (FRRI) }\end{array}$ & B6/B5 & $\begin{array}{l}\text { Barry et al. } \\
(2008)\end{array}$ \\
\hline $\begin{array}{l}\text { Green } \\
\text { Atmospherically } \\
\text { Resistant Index } \\
\text { (GARI) }\end{array}$ & $\begin{array}{l}{[\mathrm{B} 7-(\mathrm{B} 3-1.7 \mathrm{~B} 2+1.7 \mathrm{~B} 5)] /} \\
{[\mathrm{B} 7+(\mathrm{B} 3-1.7 \mathrm{~B} 2+1.7 \mathrm{~B} 5)]}\end{array}$ & $\begin{array}{l}\text { Gitelson et } \\
\text { al. (1996) }\end{array}$ \\
\hline $\begin{array}{l}\text { Green Difference } \\
\text { Vegetation Index } \\
\text { (GDVI) }\end{array}$ & B7-B3 & $\begin{array}{l}\text { Sripada et } \\
\text { al. (2006) }\end{array}$ \\
\hline $\begin{array}{l}\text { Green Normalized } \\
\text { Difference } \\
\text { Vegetation Index } \\
\text { (GNDVI) }\end{array}$ & $(\mathrm{B} 7-\mathrm{B} 3) /(\mathrm{B} 7+\mathrm{B} 3)$ & $\begin{array}{l}\text { Gitelson } \\
\text { and } \\
\text { Merzlyak } \\
\text { (1998) }\end{array}$ \\
\hline $\begin{array}{l}\text { Green Ratio } \\
\text { Vegetation Index } \\
\text { (GRVI) }\end{array}$ & B7/B3 & $\begin{array}{l}\text { Sripada et } \\
\text { al. (2006) }\end{array}$ \\
\hline $\begin{array}{l}\text { Infrared Percentage } \\
\text { Vegetation Index } \\
\text { (IPVI) }\end{array}$ & $\mathrm{B} 7 /(\mathrm{B} 7+\mathrm{B} 5)$ & $\begin{array}{l}\text { Crippen } \\
\text { (1990) }\end{array}$ \\
\hline $\begin{array}{l}\text { Leaf Area Index } \\
\text { (LAI) }\end{array}$ & $3.618[(\mathrm{~B} 7-\mathrm{B} 5) /(\mathrm{B} 7+6 \mathrm{~B} 5-7.5 \mathrm{~B} 2+1)]-0.118$ & $\begin{array}{l}\text { Boegh et } \\
\text { al. }(2002)\end{array}$ \\
\hline $\begin{array}{l}\text { Modified Non-Linear } \\
\text { Index (MNLI) }\end{array}$ & {$\left[\left(\mathrm{B}^{2}-\mathrm{B} 5\right) 1.5\right] /\left(\mathrm{B}^{2}+\mathrm{B} 5+0.5\right)$} & $\begin{array}{l}\text { Yang et al. } \\
(2008)\end{array}$ \\
\hline $\begin{array}{l}\text { Modified Simple } \\
\text { Ratio (MSR) }\end{array}$ & {$[(\mathrm{B} 7 / \mathrm{B} 5)-1] /[\operatorname{sqrt}(\mathrm{B} 7 / \mathrm{B} 5)+1]$} & $\begin{array}{l}\text { Chen } \\
(1996)\end{array}$ \\
\hline $\begin{array}{l}\text { Modified Triangular } \\
\text { Vegetation Index } \\
\text { (MTVI) }\end{array}$ & 1.2[1.2(B7-B3)-2.5(B5-B3)] & $\begin{array}{l}\text { Haboudane } \\
\text { et al. } \\
(2004)\end{array}$ \\
\hline $\begin{array}{l}\text { Normalized } \\
\text { Difference } \\
\text { Vegetation Index } \\
\text { (NDVI) }\end{array}$ & $(\mathrm{B} 7-\mathrm{B} 5) /(\mathrm{B} 7+\mathrm{B} 5)$ & $\begin{array}{l}\text { Rouse et } \\
\text { al. (1973) }\end{array}$ \\
\hline $\begin{array}{l}\text { Optimized Soil } \\
\text { Adjusted } \\
\text { Vegetation Index } \\
\text { (OSAVI) }\end{array}$ & {$[1.5(\mathrm{~B} 7-\mathrm{B} 5)] /(\mathrm{B} 7+\mathrm{B} 5+0.16)$} & $\begin{array}{l}\text { Rondeaux } \\
\text { et al. } \\
(1996)\end{array}$ \\
\hline $\begin{array}{l}\text { Red Green Ratio } \\
\text { Index (RGI) }\end{array}$ & B5/B3 & $\begin{array}{l}\text { Gamon } \\
\text { and Surfus } \\
\text { (1999) }\end{array}$ \\
\hline $\begin{array}{l}\text { Renormalized } \\
\text { Difference } \\
\text { Vegetation Index } \\
\text { (RDVI) }\end{array}$ & $(\mathrm{B} 7-\mathrm{B} 5) /[\mathrm{sqrt}(\mathrm{B} 7+\mathrm{B} 5)]$ & $\begin{array}{l}\text { Roujean } \\
\text { and Breon } \\
(1995)\end{array}$ \\
\hline Transformed & $\operatorname{sqrt}[0.5+(B 7-B 5) /(B 7+B 5)]$ & Bannari et \\
\hline
\end{tabular}


Table 4

First and second order textures extracted for each surface reflectance bands. On first order textures, $p_{i}$ is the relative frequency of the $i$ gray levels in the window, $X$ is the pixel gray level and $N$ is the number of gray levels. On second order textures, $p(i, j)$ represents the value in $i, j$ cell of the co-occurrence matrix and $N$ is the number of gray levels used in the analysis.

\begin{tabular}{|c|c|c|}
\hline Texture & Description $^{\mathrm{a}}$, b & Formula $^{\mathrm{c}}$ \\
\hline \multicolumn{3}{|l|}{ First order } \\
\hline Data range & $\begin{array}{l}\text { Difference of the maximum and } \\
\text { minimum pixel value in the moving } \\
\text { window. }\end{array}$ & $\max \{X\}-\min \{X\}$ \\
\hline Mean & $\begin{array}{l}\text { Local mean of pixels in the moving } \\
\text { window. }\end{array}$ & $\sum_{i=0}^{N-1} i p_{i}=S_{M}$ \\
\hline Variance & $\begin{array}{l}\text { Local variance of pixels in the moving } \\
\text { window. }\end{array}$ & $\sum_{i=0}^{N-1}\left(i-S_{M}\right)^{2} p_{i}=S_{D}^{2}$ \\
\hline Entropy & Shannon diversity index. & $\sum_{i=0}^{N-1} p_{i}\left(-\ln p_{i}\right)$ \\
\hline Skewness & $\begin{array}{l}\text { Lack of symmetry around the mean of } \\
\text { the moving window pixels. }\end{array}$ & $\frac{1}{S_{D}^{3}}\left[\sum_{i=0}^{N-1}\left(i-S_{M}\right)^{3} p_{i}\right]$ \\
\hline \multicolumn{3}{|l|}{ Second order } \\
\hline Mean & Local mean of GLCM window. & $\sum_{i, j=0}^{N-1} i p(i, j)=\mu$ \\
\hline Variance & Local variance of GLCM window. & $\sum_{i, j=0}^{N-1} p(i, j)(i-\mu)^{2}$ \\
\hline Homogeneity & $\begin{array}{l}\text { Measurement of homogeneous pixel } \\
\text { values through image. The values } \\
\text { range between } 0 \text { and } 1 .\end{array}$ & $\sum_{i, j=0}^{N-1} \frac{p(i, j)}{1+(i, j)^{2}}$ \\
\hline Contrast & $\begin{array}{l}\text { Measurement of the local variation in } \\
\text { the image. Opposed to homogeneity. }\end{array}$ & $\sum_{i, j=0}^{N-1} p(i, j)(i-j)^{2}$ \\
\hline Dissimilarity & $\begin{array}{l}\text { Similar to the contrast, measured as } \\
\text { the absolute value of grayscale } \\
\text { differences. }\end{array}$ & $\sum_{i, j=0}^{N-1} p(i, j)|i-j|$ \\
\hline Entropy & $\begin{array}{l}\text { Shannon diversity index. The values } \\
\text { range between } 0 \text { and the natural } \\
\text { logarithm of the GLCM window size. }\end{array}$ & $\sum_{i, j=0}^{N-1} p(i, j)(-\ln p(i, j))$ \\
\hline $\begin{array}{l}\text { Angular second } \\
\text { moment }\end{array}$ & $\begin{array}{l}\text { Measure of the image homogeneity. } \\
\text { The values range between } 0 \text { and } 1 \text {. }\end{array}$ & $\sum_{i, j=0}^{N-1} p(i, j)^{2}$ \\
\hline Correlation & $\begin{array}{l}\text { Measurement of linear dependencies } \\
\text { of the image gray levels. The values } \\
\text { range between }-1 \text { and } 1 \text {. }\end{array}$ & $\sum_{i, j=0}^{N-1} p(i, j) \frac{\left(i-\mu_{i}\right)\left(j-\mu_{j}\right)}{\sqrt{\sigma_{i}^{2} \sigma_{j}^{2}}}$ \\
\hline \multicolumn{3}{|c|}{ a Haralick et al. (1973). ${ }^{* *}$} \\
\hline \multicolumn{3}{|c|}{ b Wood et al. (2012). } \\
\hline
\end{tabular}

the four spatial directions $\left(0^{\circ}, 45^{\circ}, 90^{\circ}\right.$ and $135^{\circ}$, represented in this case by the Cartesian coordinates $[1,0],[1,-1],[0,-1]$ and $[-1,-1])$. The directionally invariant texture measures were subsequently obtained by calculating the mean of the co-occurrence measurements in the four directions (Zhang and Xie, 2012).

\subsection{Statistical analysis}

The relationship between biotic variables accounting for post-fire regeneration (Table 2) and spectral predictors (Tables 3 and 4) was analyzed using multivariate Generalized Linear Models (GLMs; McCullagh and Nelder, 1989). For each biotic variable, we tested five sets of predictors: reflectance values, spectral indices, first order textures, second order textures and ensemble ([reflectance + spectral indices + textures $]$ ). We calibrated separate models for each recurrence-severity scenario and for the entire study framework. Therefore, we ran a total number of 375 models ( 15 biotic variables $\times 5$ sets of spectral predictors $\times 5$ frameworks). For modelling biotic variables related to vegetation height, we assumed a normal error distribution and an identity link function (linear model). For count variables, a Poisson distribution of error with a logarithmic link function (Zeileis et al., 2008) was used; in the case of overdispersion occurrence, a quasi-Poisson distribution type with a logarithmic link function (Ver-Hoef and Boveng, 2007) was carried out. For response variables measured as a percentage, we used a quasi-Poisson type error distribution with a logarithmic link function, according to Martin et al. (2005).

In order to detect multicollinearity problems within each set of predictors, bivariate Pearson correlations and VIF values were evaluated. Correlation analyses allowed for discriminating strongly correlated groups of predictors $\left(r_{\text {Pearson }}>0.7\right.$ ) (Engler et al., 2013). Within each group, we only preserved for subsequent analysis the predictor that explained the greatest proportion of variance for a given response variable in univariate generalized linear models (GLMs) (McCullagh and Nelder, 1989). The uncorrelated predictors that were used in the calibration of post-fire regeneration models are shown in Table SM.1 (Supplementary Material). Additionally, we checked that the variance inflation factor (VIF) of each predictor included in the models was lower than four (Zuur et al., 2010). Models were calibrated in a backwards stepwise regression procedure (Draper and Smith, 1998). The overall fit of the models was evaluated as the proportion of deviance explained by the predictors (McFadden, 1974) and the predictive power as the root mean square error (RMSE, Eq. (1)) normalized from the maximum $\left(y_{\max }\right)$ and minimum $\left(y_{\min }\right)$ value of observations for each response variable (nRMSE, Eq. (2)).

$$
\begin{aligned}
& R M S E=\sqrt{\frac{1}{n} \sum_{i=1}^{n}\left(\AA_{i}-y_{i}\right)^{2}} \\
& n R M S E=\frac{R M S E}{y_{\max }-y_{\min }} \times 100
\end{aligned}
$$

All statistical analyses were performed using R (Core Team, 2015).

\section{Results}

The highest recovery of the Pinus pinaster population structure variables (density, cover and height of pine seedlings) was observed for the low fire recurrence scenario. Fire severity was inversely related to the population recovery in both fire recurrence scenarios. The opposite pattern was observed for the understory community structure variables, which exhibited greater recovery under high fire recurrence than for the low recurrence scenario. There was no clear pattern for the influence of fire severity in the community structure recovery (Table 5).

The highest model fit (Table 6) and predictive capacity (Fig. 4) was found, for the whole study framework, in either the models including texture predictors or the ensemble model (spectral indices + textures). Pinus pinaster structure was modeled both in terms of number (Pn) (deviance $=34 \%$ and nRMSE $=16 \%$ ) and cover (Pcov) of pine seedlings (deviance $=39 \%$ and $\mathrm{nRMSE}=17 \%$ ) from the second order textures and the ensemble set (spectral indices + first order textures), respectively. At the understory community level, the biotic variable most successfully modeled was the cover of woody species (Wcov) (deviance $=58 \%-63 \%$ and nRMSE $=9 \%-11 \%$ for the considered set of predictors), with all sets of predictors having a similar performance. The overall fit and nRMSE of the other understory community variables were lower than $45 \%$ and $27 \%$, respectively.

None of the reflectance bands explained the recovery of the Pinus pinaster population. However, bands 1 (coastal blue) and 7 (NIR-1) were significantly correlated with the understory community structure. For its part, band 6 (red edge) was related with the cover of leaves, lying necromass and stones (Table 7). Among the spectral indices, Anthocyanin Reflectance Index 2 significantly explained the structure variables related to the regeneration of the Pinus pinaster population and the understory community. The Burnt Area Index and the WorldView Soil Index were the best predictors of the cover of leaves, lying necromass and bare soil at community level (Table 7). In all models analyzed, at least one variable within the set of first and second order textures was selected as a significant predictor of post-fire vegetation structure. Among first order textures, the mean and data range of different bands had the highest level of significance. For the second order textures, the mean also gained special relevance, along with entropy and homogeneity (Table 7). None of the set of predictors explained the 
Table 5

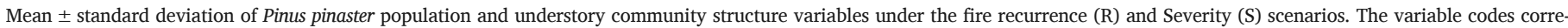
spond to that shown in Table 2.

\begin{tabular}{|c|c|c|c|c|}
\hline & lowR-lows & lowR-highs & highR-lowS & highR-highS \\
\hline Pn (number) & $5.35 \pm 5.18$ & $3.13 \pm 4.55$ & $0.73 \pm 1.05$ & $0.34 \pm 0.90$ \\
\hline dPn (number) & $0.33 \pm 0.66$ & $0.24 \pm 0.81$ & $0.04 \pm 0.14$ & $0.00 \pm 0.00$ \\
\hline $\mathrm{Ph}(\mathrm{cm})$ & $18.80 \pm 9.15$ & $23.36 \pm 14.10$ & $17.20 \pm 9.78$ & $28.62 \pm 19.25$ \\
\hline Pmaxh (cm) & $32.88 \pm 18.14$ & $34.45 \pm 23.23$ & $13.16 \pm 16.56$ & $13.08 \pm 22.38$ \\
\hline Pminh (cm) & $7.69 \pm 4.13$ & $10.91 \pm 10.26$ & $6.08 \pm 7.68$ & $8.77 \pm 16.28$ \\
\hline Pcov (\%) & $8.01 \pm 7.85$ & $6.72 \pm 7.91$ & $1.16 \pm 1.68$ & $0.97 \pm 2.27$ \\
\hline Wcov (\%) & $44.96 \pm 14.79$ & $41.29 \pm 14.67$ & $50.69 \pm 14.21$ & $50.19 \pm 15.87$ \\
\hline Wmaxh $(\mathrm{cm})$ & $68.55 \pm 17.79$ & $73.02 \pm 18.26$ & $86.77 \pm 33.58$ & $82.33 \pm 22.70$ \\
\hline Wrich (number) & $2.41 \pm 1.02$ & $2.45 \pm 0.91$ & $3.22 \pm 0.59$ & $2.97 \pm 0.50$ \\
\hline Hcov $(\%)$ & $3.84 \pm 9.32$ & $2.06 \pm 2.54$ & $1.06 \pm 1.68$ & $0.64 \pm 1.12$ \\
\hline Hrich (number) & $1.31 \pm 1.32$ & $1.41 \pm 1.31$ & $0.50 \pm 0.72$ & $0.28 \pm 0.42$ \\
\hline Lcov $(\%)$ & $17.28 \pm 12.39$ & $10.96 \pm 12.45$ & $5.46 \pm 11.77$ & $0.75 \pm 1.52$ \\
\hline Ncov (\%) & $10.06 \pm 10.57$ & $12.98 \pm 10.06$ & $3.57 \pm 5.46$ & $3.72 \pm 3.78$ \\
\hline St $(\%)$ & $17.65 \pm 11.79$ & $13.80 \pm 14.28$ & $23.42 \pm 14.49$ & $25.86 \pm 14.08$ \\
\hline S (\%) & $12.88 \pm 8.82$ & $24.35 \pm 15.58$ & $20.88 \pm 10.66$ & $20.15 \pm 11.38$ \\
\hline
\end{tabular}

Table 6

Explained deviance by the regeneration models run for the entire study framework (see Table 2 for the codes of the response variables).

\begin{tabular}{|c|c|c|c|c|c|c|}
\hline \multirow[t]{2}{*}{ Category } & \multirow[t]{2}{*}{ Response variable } & \multicolumn{5}{|c|}{ Set of predictors } \\
\hline & & Reflectance & Indices & 1rd textures & 2rd textures & Ensemble \\
\hline \multirow[t]{6}{*}{ Pinus pinaster population } & $\mathrm{Pn}$ & - & $26.66 \%$ & $27.85 \%$ & $26.79 \%$ & $33.63 \%$ \\
\hline & $\mathrm{dPn}$ & - & - & - & - & - \\
\hline & $\mathrm{Ph}$ & - & $25.97 \%$ & $29.21 \%$ & $27.59 \%$ & - \\
\hline & Pmaxh & - & $40.82 \%$ & $13.13 \%$ & $12.13 \%$ & $16.49 \%$ \\
\hline & Pminh & - & - & - & - & - \\
\hline & Pcov & - & - & $27.08 \%$ & $38.63 \%$ & - \\
\hline \multirow[t]{9}{*}{ Understory community } & Wcov & $62.84 \%$ & $60.80 \%$ & $63.02 \%$ & $61.51 \%$ & $57.90 \%$ \\
\hline & Wmaxh & $27.88 \%$ & $38.15 \%$ & $33.04 \%$ & $42.88 \%$ & $44.73 \%$ \\
\hline & Wrich & $23.07 \%$ & $24.39 \%$ & $27.75 \%$ & $33.09 \%$ & $36.41 \%$ \\
\hline & Hcov & - & - & $8.63 \%$ & $14.80 \%$ & - \\
\hline & Hrich & - & - & - & - & - \\
\hline & Lcov & $17.60 \%$ & $21.83 \%$ & $22.23 \%$ & $35.98 \%$ & $38.83 \%$ \\
\hline & Ncov & $15.46 \%$ & $34.95 \%$ & $23.12 \%$ & $29.67 \%$ & $39.24 \%$ \\
\hline & St & $4.66 \%$ & $3.46 \%$ & $10.68 \%$ & $14.20 \%$ & - \\
\hline & $\mathrm{S}$ & - & $33.07 \%$ & - & - & $35.48 \%$ \\
\hline
\end{tabular}

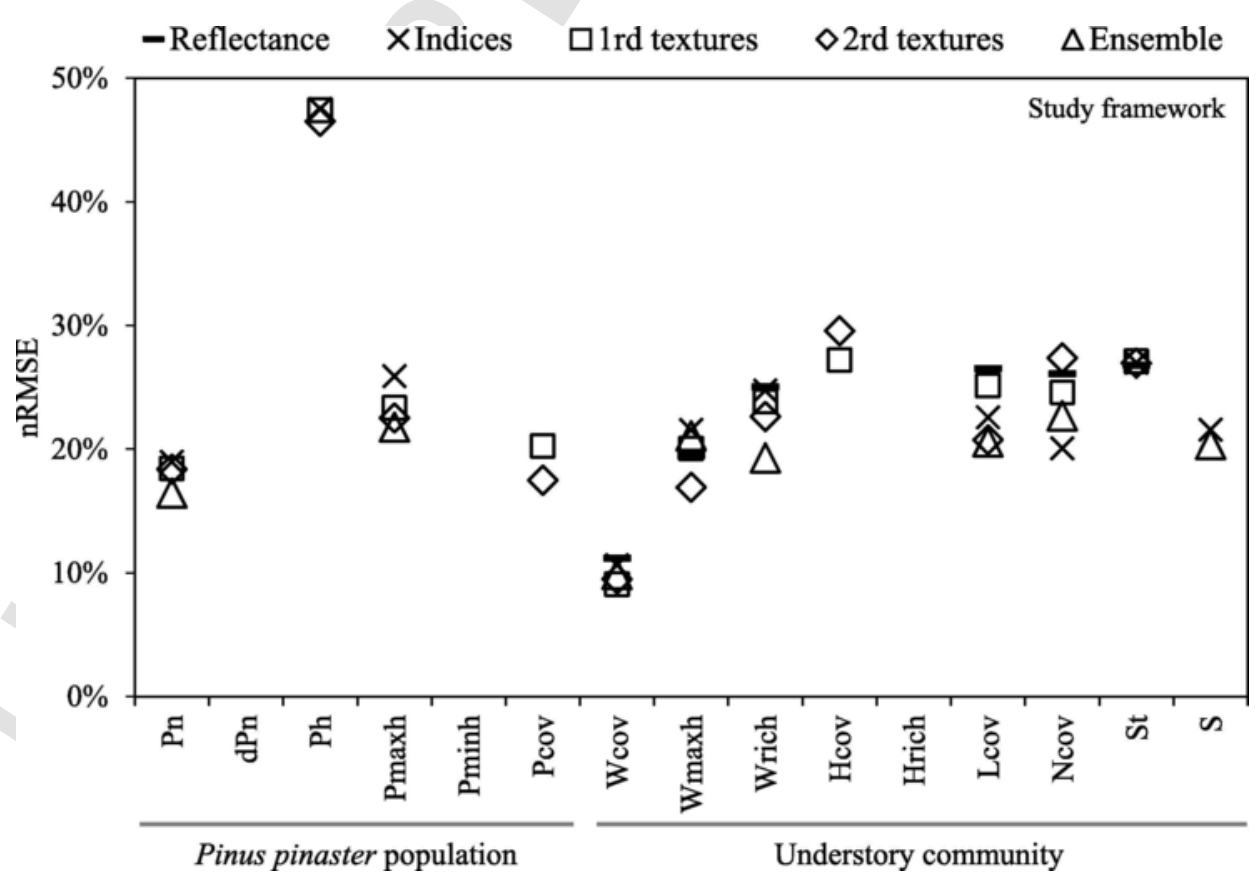

Fig. 4. Normalized root mean square error (nRMSE) of the regeneration models calibrated for the entire study framework (see Table 2 for the codes of the response variables). 
Table 7

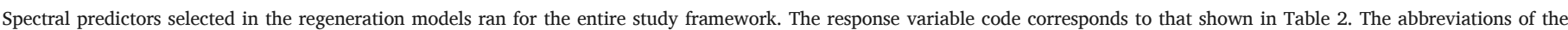

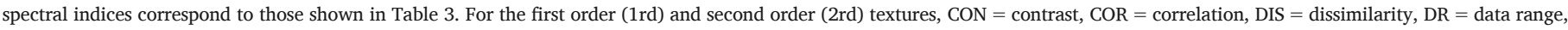
$\mathrm{ENT}=$ entropy, $\mathrm{HOM}=$ homogeneity, $\mathrm{MEAN}=$ mean and $\mathrm{VAR}=$ variance.

\begin{tabular}{|c|c|c|c|c|c|c|}
\hline Category & $\begin{array}{l}\text { Response } \\
\text { variable }\end{array}$ & Reflect. & $\begin{array}{l}\text { Spectral } \\
\text { indices }\end{array}$ & First order textures & Second order textures & Ensemble model \\
\hline \multirow[t]{6}{*}{$\begin{array}{r}\text { Pinus pinaster } \\
\text { population }\end{array}$} & Pn & - & $\begin{array}{l}\text { ARI }^{* * *} \text {, } \\
\text { PSRI", }^{*} \\
\text { WSI** }^{*}\end{array}$ & $\mathrm{~B} 7\left(D R^{* * * *}\right)$ & $\mathbf{B} 7\left(E N T^{* *}\right)$ & $\mathrm{ARI}^{* *}, \mathrm{PSRI}^{*}, 1 \mathrm{rd}\left[\mathrm{B} 4\left(\mathrm{ENT}^{* *}\right), \mathrm{B} 7\left(\mathrm{DR}^{* * *}\right)\right]$ \\
\hline & $\mathrm{dPn}$ & - & - & - & - & - \\
\hline & $\mathrm{Ph}$ & - & $\begin{array}{l}\text { MTVI", } \\
\text { PRI*, }^{*}{ }^{*} I^{*}\end{array}$ & B4 $\left(D R^{*} \cdot M E A N^{* *}\right)$ & $\mathbf{B 8}\left(M E A N^{* *}\right)$ & - \\
\hline & Pmaxh & - & PSRI $^{*}$ & $\mathrm{~B} 4\left(D R^{* * *}\right) \mathrm{B} 7\left(D R^{* * * *}\right)$ & $\mathbf{B} 7\left(H O M^{* * *}\right) \mathbf{B} 8\left(M E A N^{*}\right)$ & $\begin{array}{l}\text { MTVI", } 2 \text { rd }\left[\mathrm{B} 3\left(H O M^{* *}\right), \mathbf{B} 7\left(H O M^{* * *}\right),\right. \\
\left.\text { B8 }\left(\mathrm{COR}^{*}\right)\right]\end{array}$ \\
\hline & Pminh & - & - & - & - & - \\
\hline & Pcov & - & - & $\mathbf{B 8}\left(D R^{* *}\right)$ & B3 $\left(M E A N^{* * * *}, E N T^{* *}\right)$ B6 $\left(M E A N^{* * * *}\right)$ & - \\
\hline \multirow[t]{9}{*}{$\begin{array}{l}\text { Understory } \\
\text { community }\end{array}$} & Wcov & $\begin{array}{l}\mathrm{B} 1^{* * * *}, \\
\mathrm{~B}^{* * * *}\end{array}$ & $\begin{array}{l}\mathrm{ARI}^{* * * *} \\
\mathrm{WSI}^{*}\end{array}$ & $\begin{array}{l}\text { B3 }\left(D R^{*}\right) \text { B5 }\left(M E A N^{* * *}\right) \\
\text { B8 }\left(D R^{* * *}, M E A N^{* * *}\right)\end{array}$ & $\begin{array}{l}\text { B1 }\left(M E A N^{* * * *}\right) \text { B2 }\left(C O R^{*}\right) \text { B3 }\left(E N T^{*}\right) \\
\text { B7 }\left(M E A N^{* * * *}\right)\end{array}$ & $\begin{array}{l}\mathrm{GDVI}^{* * * *}, 1 \mathrm{rd}\left[\mathrm{B} 3\left(D R^{*}\right), \mathbf{B} 5\left(M E A N^{* * * *}\right)\right. \\
\left.\text { B8 }\left(D R^{* * *}\right)\right]\end{array}$ \\
\hline & Wmaxh & $\mathrm{B} 1^{* * * *}$ & $\begin{array}{l}\text { ARI }^{* * *}, \\
\text { PSRI }^{* * *}\end{array}$ & B5 $\left(\mathrm{MEAN}^{* * * *}\right)$ & $\begin{array}{l}\text { B1 }\left(E N T^{*}\right) \text { B4 }\left(M E A N^{* * *}\right) \text { B6 }\left(M E A N^{* *}\right) \\
\text { B7 }\left(C O R^{*}\right)\end{array}$ & $\mathrm{ARI}^{* * *}, \mathrm{PSRI}^{* * *}, 1 \mathrm{rd}\left[\mathrm{B} 5\left(M E A N^{* * * *}\right)\right]$ \\
\hline & Wrich & $\begin{array}{l}\mathrm{B} 1^{* * * *} \\
\mathrm{~B} 7^{* * * k}\end{array}$ & $\begin{array}{l}\mathrm{ARI}^{* * * *} \\
\mathrm{BAI}^{* * * *}\end{array}$ & $\begin{array}{l}\text { B1 }\left(M E A N^{* * *}\right) \\
\text { B8 }\left(M E A N^{* * *}\right)\end{array}$ & B1 $\left(M E A N^{* *}\right) \mathbf{B 8}\left(M E A N^{* * *}, H O M^{* *}\right)$ & $\mathrm{ARI}^{* *}, \mathrm{BAI}^{* * * *}, 2 \mathrm{rd}\left[\mathrm{B} 3\left(H O M^{* * *}\right), \mathbf{B 8}\left(C O N^{* *}\right)\right]$ \\
\hline & Hcov & - & - & $\mathbf{B} 3\left(D R^{* * *}\right) \mathbf{B 8}\left(D R^{* * *}\right)$ & B3 $\left(D I S^{* * * *}\right)$ B6 $\left(D I S^{* * * *}\right)$ & - \\
\hline & Hrich & - & - & - & - & - \\
\hline & Lcov & $\mathrm{B} 6^{* * *}$ & $\begin{array}{l}\text { BAI }^{* * * *} \text {, } \\
\text { FRRI" }^{*}, \\
\text { WSI }^{*}\end{array}$ & B6 $\left(M E A N^{* * *}, E N T^{*}\right)$ & $\mathbf{B} 2\left(E N T^{* * *}\right) \mathbf{B} 7\left(H O M^{* * *}\right)$ & $\mathrm{FRRI}^{*}, \mathrm{GEMI}^{*}, 2 \mathrm{rd}\left[\mathrm{B2}\left(E N T^{* * * *}\right), \mathbf{B} 7\left(H O M^{* * *}\right)\right]$ \\
\hline & Ncov & $\mathrm{B} 6^{* *}$ & $\mathrm{BAI}^{* * *}$ & $\begin{array}{l}\text { B4 }\left(M E A N^{* *}, E N T^{*}\right) \\
\text { B7 }\left(M E A N^{* * *}\right)\end{array}$ & $\begin{array}{l}\text { B2 }\left(E N T^{*}\right) \text { B4 }\left(C O R^{*}\right) \text { B5 }\left(E N T^{*}\right) \\
\text { B6 }\left(D I S^{* * * *}, C O R^{*}\right) \text { B7 }\left(M E A N^{* * *}\right)\end{array}$ & $\begin{array}{l}\mathrm{BAI}^{* * *}, 2 \mathrm{rd}\left[\mathrm{B} 2\left(E N T^{*}\right), \mathrm{B} 4\left(C O R^{*}\right),\right. \\
\left.\mathrm{B} 6\left(D I S^{* *}, C O R^{*}\right), \mathrm{B} 7\left(E N T^{*}\right), \mathbf{B 8}\left(C O R^{*}\right)\right]\end{array}$ \\
\hline & St & $\mathrm{B} 6^{*}$ & $\begin{array}{l}\text { FRRI*, } \\
\text { GEMI }^{*}\end{array}$ & $\mathrm{~B} 6\left(D R^{*}, M E A N^{* * * *}\right)$ & B6 $\left(M E A N^{* * *}, E N T^{*}, C O R^{*}\right)$ & \\
\hline & $\mathrm{S}$ & - & $\mathrm{WSI}^{* *}$ & - & & $\mathrm{WSI}^{* *}, \operatorname{1rd}\left[\mathrm{B} 5\left(D R^{*}\right)\right]$ \\
\hline
\end{tabular}

number of dead pine seedlings or the minimum height of living pine seedlings.

For the recurrence-severity scenarios, the overall fit and predictive capacity of the regeneration models ran at population level were similar to those found for the entire study framework, except for the high recurrence and severity scenario (Fig. 5). In the latter case, the nRMSE rose to $52 \%$ for the number (Pn), $41 \%$ for the cover (Pcov), $62 \%$ for average height $(\mathrm{Ph})$ and $45 \%$ for maximum height (Pmaxh) of living seedlings. The prediction of community level variables (except necromass cover -Ncov-) under the different scenarios presented the same performance in terms of fit and predictive capacity than for the entire study framework. For Ncov, the predictive power of the model was significantly lower in the scenarios defined by a high recurrence (nRMSE higher than 40\%).

The recovery models for the entire study framework that achieved the highest predictive capacity (nRMSE around 20\% or lower) are shown in Table 8 . These models explained the variation corresponding to the dominant tree species regeneration ( $\mathrm{Pn}$ and Pcov), understory woody species regeneration (Wcov, Wmaxh and Wrich), necromass cover (Ncov) and percentage of bare soil (S). The spatial outputs of the best performing models at population and understory community levels (Pn and the Wcov) are shown in Figs. 6 and 7 (see Figures SM.1 to SM.5 of the Supplementary Material for the maps of remaining models). From these model spatial outputs, priority areas to apply post-fire management strategies could be identified.

\section{Discussion}

Spectral products derived from satellite imagery at high spatial resolution, such as WorldView-2, represent a useful tool for a rapid assessment of the vegetation regeneration after the occurrence of large forest fires in Mediterranean fire prone ecosystems. Key biotic variables, which are valuable indicators of the structure and functioning of both
Pinus pinaster population (i.e., number and cover of living seedlings) and the understory community (i.e., cover, maximum height and richness of woody species, necromass cover and percentage of bare soil) have been successfully modeled under different fire regimes (recurrence and severity) on the basis of texture predictors, which has clear implications for land management in areas affected by mega-fires. The assessment of post-fire recovery at different ecosystem levels is a key approach to avoid harmful environmental processes such as post-fire erosion, the loss of ecosystem services supplies or the occurrence of a new forest fire in the same area. For instance, within our study area, it would be a priority to evaluate the dominant tree species and the understory community structure recovery within the high and low fire recurrence scenarios, respectively, given their low regeneration observed under those conditions. The methodology proposed in this study may be applied to other high spatial resolution remote sensors available for land managers, which channels cover similar regions of the electromagnetic spectrum.

Pinus pinaster seedlings presents a different spectral response in relation to the surrounding understory vegetation, especially in the NIR region (Viedma et al., 2012) (Figure SM.6 of the Supplementary Material), given its geometry and leaf characteristics (Rautiainen, 2005). These spectral differences along with the regeneration ability of the pine population allowed for satisfactory modeling of the variables corresponding to the number and cover of Pinus pinaster seedlings for the entire study framework. However, for the case of the high recurrence and severity scenario, where the number of seedlings was very small and situated under a dense shrub canopy, neither spectral information nor textures could explain the population recovery due to the small contribution of the seedlings to the overall reflectance of the plots (Viedma et al., 2012).

The Pinus pinaster seedling prediction model was calibrated with Anthocyanin Reflectance Index 2 and Plant Senescence Reflectance Index, along with the first order textures corresponding to the yellow re- 

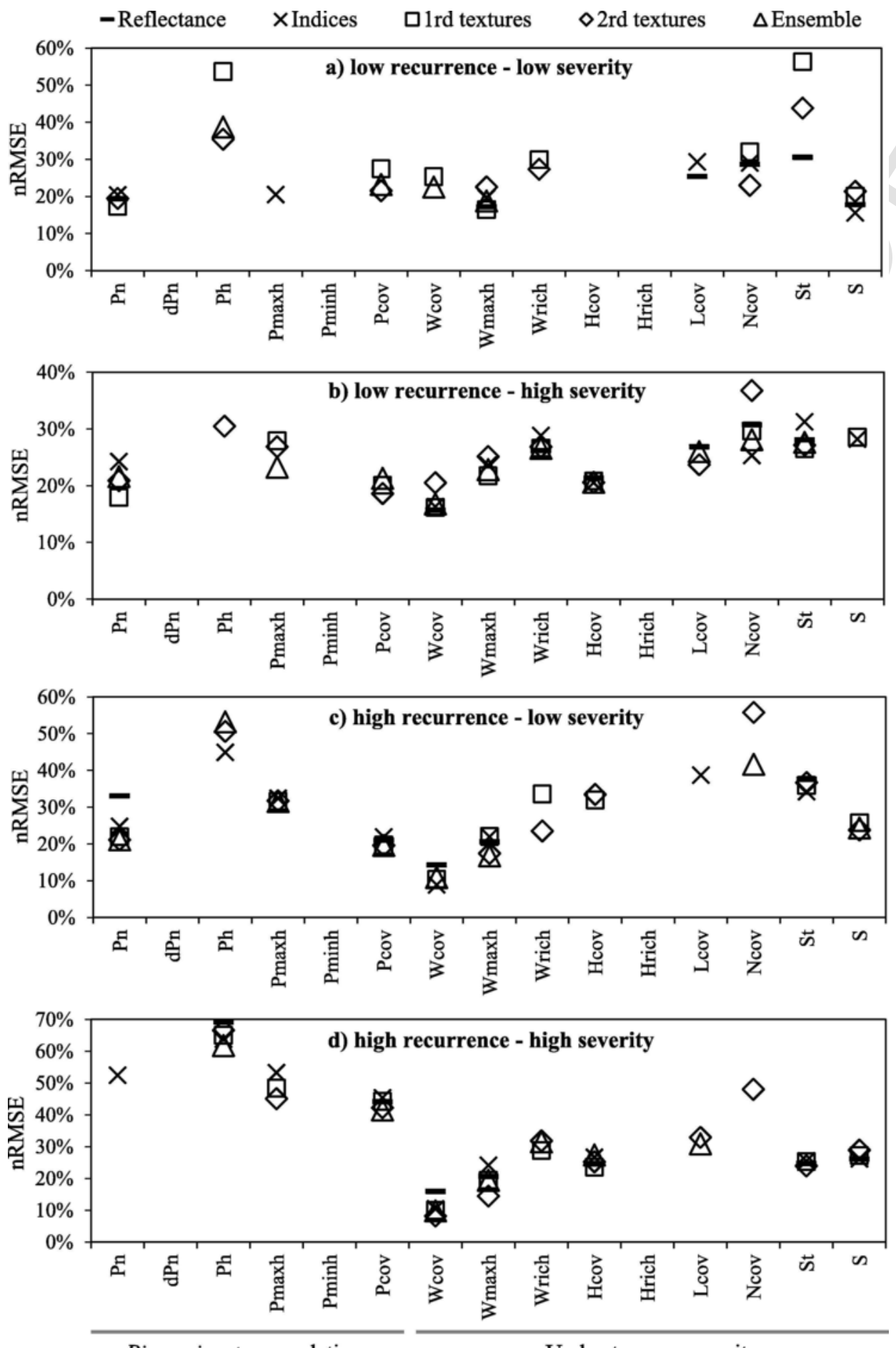

Pinus pinaster population

Understory community

Fig. 5. Normalized root mean square error (nRMSE) of the regeneration models ran for the scenarios of recurrence and severity (see Table 2 for response variable codes).

gion entropy and NIR-1 data range. The two spectral indices were negatively correlated with the number of pine seedlings, since these indices measure plant stress from anthocyanins and carotenoids detection (Merzlyak et al., 1999; Gitelson et al., 2001). Significant anthocyanins and carotenoids accumulation in this phenological stage is induced, for example, as a result of stress caused by increased solar radiation received by the plant, presence of wounds or competitive effects (Lee and Graham, 1986). These environmental stress conditions are characteristic after the occurrence of a forest fire and a higher plant stress intensity caused by the competitive effects of resprouter understory species could adversely affect the recruitment of Pinus pinaster seedlings (Calvo et al., 2008; Taboada et al., 2017). Similarly, the entropy texture of the yellow region presents a negative correlation with the number of living pine seedlings. This fact can be explained because this region can be used to detect the characteristic vegetation "yellowness" under certain conditions, such as plant stress (Immitzer et al., 2012), and therefore a greater diversity of reflectance values in this region of the spectrum could present an inverse relationship with the number of Pinus pinaster seedlings. The direct correlation between the data range in the NIR-1 region and the number of pine seedlings could be explained because re- 
Table 8

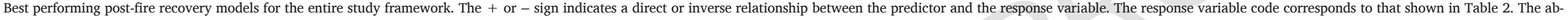

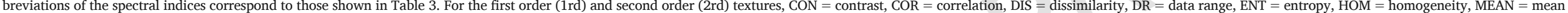
and $\mathrm{VAR}=$ variance.

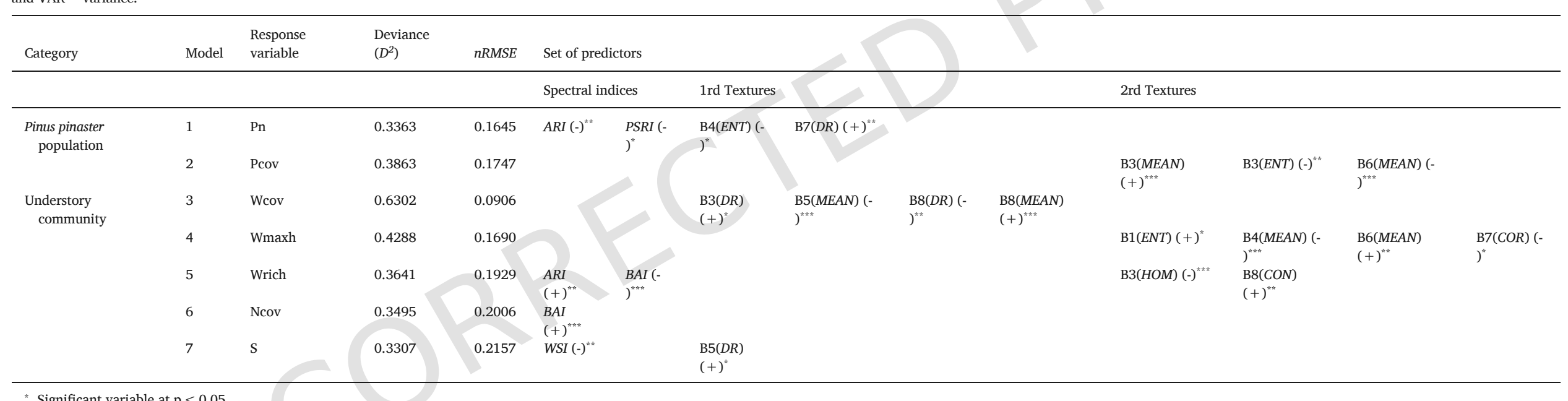

Significant variable at $\mathrm{p}<0.05$

.* Significant variable at $\mathrm{p}<0.01$.

* Significant variable at $\mathrm{p}<0.001$. 


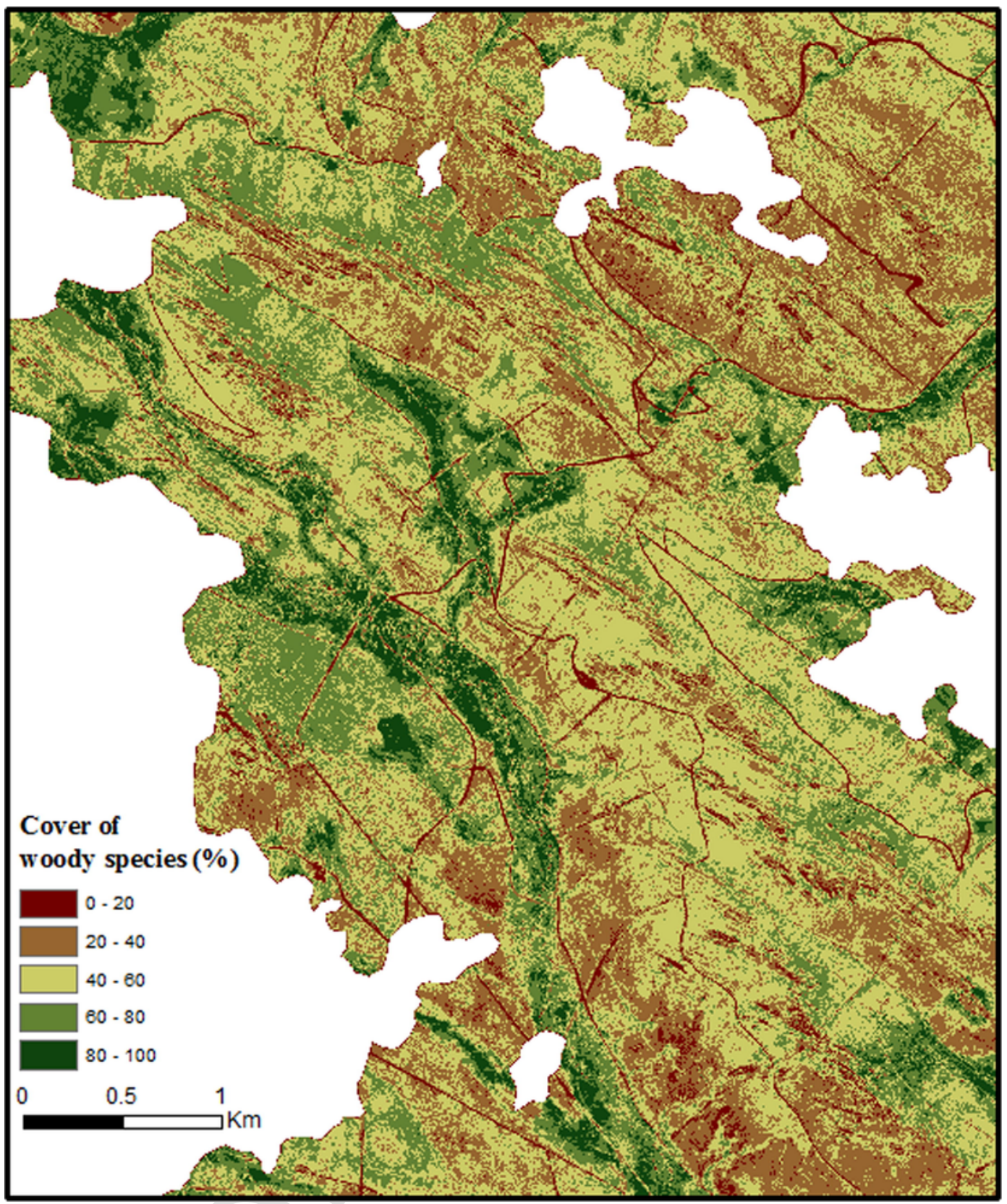

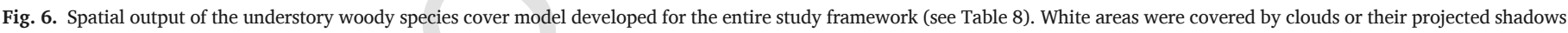
in the raw WorldView-2 image and, therefore, were masked at the processing stage.

flectance in this region varies substantially for different types of vegetation cover, such as conifers and understory woody species, this band being really effective in the discrimination of different vegetation types (DigitalGlobe, 2010; Immitzer et al., 2012; Viedma et al., 2012). The Pinus pinaster seedling prediction model represent an important base for land management decision-making in fire-prone pine systems given its predictive capacity. This tool may assist land managers in identifying areas where external intervention could be necessary to facilitate the regeneration of the dominant tree species and recover their ecosystem services supply.

The cover, height and richness of woody species (in addition to the percentage of bare soil, necromass and leaves) were the post-fire regeneration variables of the understory community with the best predictive capacity. Despite the heterogeneity of land cover still present in the study area, the successful modeling of the understory community vari- ables could be explained by the high regeneration ability of most of the understory species (Calvo et al., 2008) without the competitive effects of trees, along with the high spatial resolution of the WorldView-2 image. Wood et al. (2012) reported that the use of satellite imagery at lower spatial resolution than that provided by WorldView-2 would not allow the identification of land cover changes given the spatial variability of these heterogeneous systems. In addition, the use of moderate spatial resolution sensors, such as Landsat, involve a sub-pixel mixing question (Veraverbeke et al., 2012) and would require the application of sub-pixel image analysis techniques (Quintano et al., 2012; Fernández-Manso et al., 2016).

The model of the woody understory species cover calibrated from first-order textures presents a predictive error of only $9 \%$, both in the entire study framework and under different recurrence-severity scenarios. This is a relatively low error considering the difficulty in discrimi- 


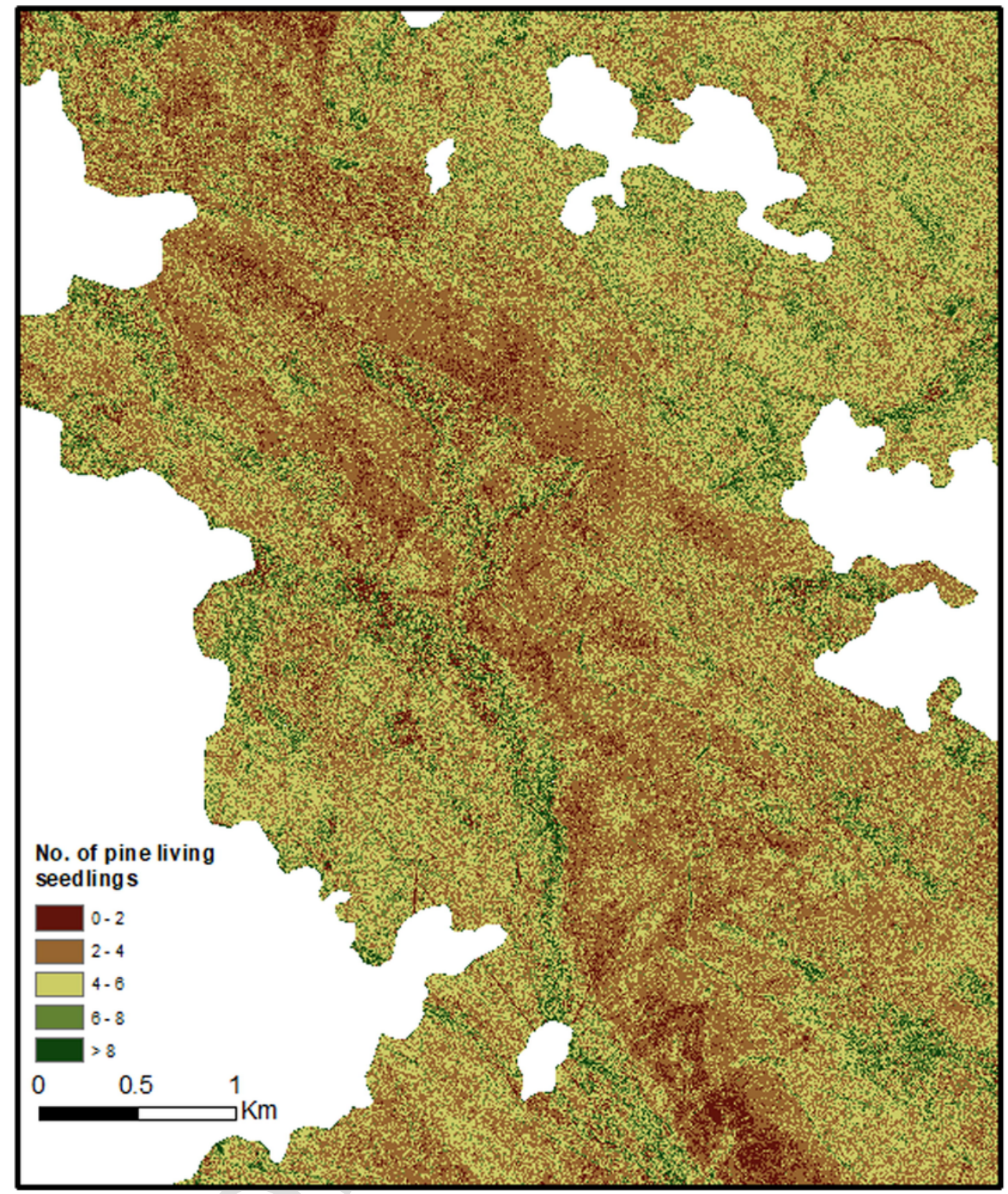

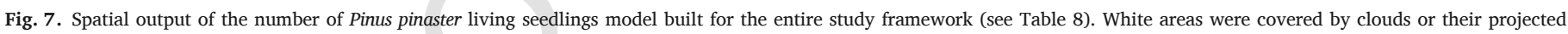
shadows in the raw WorldView-2 image and, therefore, were masked at the processing stage.

nating covers from multispectral bands comparing to hyperspectral sensors in large systems with high spatial heterogeneity (Yue et al., 2012). The model predictors with the highest significance are the mean reflectance of both red and NIR-2 regions. The mean red reflectance is inversely correlated with vegetation cover since pigments from photosynthetically active vegetation absorb a large part of this wavelength radiation (Elvidge and Chen, 1995). Meanwhile, the mean of NIR-2 region has a direct correlation with the vegetation cover since the internal structures of leaves actively reflect this radiation (Slaton et al., 2001). The correlation of the NIR-2 data range with vegetation cover is inverse, since a wider range of reflectance values in this region indicates the presence of other covers along with the vegetation. The model output could be used as a tool by land managers to define potential areas of post-fire erosion with low vegetation recovery (Storey et al., 2016) and to detect areas of high fuel continuity in case of the occurrence of a new wildfire.
The richness of woody species was successfully modeled in terms of the homogeneity and contrast of green and NIR-2 bands, respectively. Vegetation patches with high species richness are more heterogeneous than patches with a lower richness. Therefore, the spectral homogeneity of the green band had an inverse correlation with species richness, while the correlation of NIR-2 band contrast was direct. Viedma et al. (2012) found the same patterns between species richness and textural features in their study at several spatial scales with the QuickBird satellite.

The maximum height of the woody species model calibrated from image texture data had a better predictive capacity than when calibrated from spectral data alone, as demonstrated by Ozdemir and Karnieli (2011). The texture of the satellite imagery will be more uniform when the vegetation consists in short and small individuals (Petrou et al., 2012; Petrou et al., 2015), which could explain the di- 
rect and the inverse relationship of the coastal blue band entropy and the NIR-1 band correlation, respectively, with the maximum height of the woody species. For its part, the prediction error of the model was in line with the study conducted by Kayitakire et al. (2006), in which the top height of the canopy was modeled on the basis of texture features extracted from high spatial resolution satellite imagery. Although the accepted fact that optical sensors can only estimate vegetation height up to the canopy closure (Donoghue and Watt, 2006), this concern was not present in our study area because of the pine population seedlings and the understory vegetation structure consists on a unique vertical layer.

Other spatially explicit models of the understory community, such as necromass and bare soil cover, offer a relevant ecological basis for post-fire decision management in situations of soil loss erosion and accumulation of dead biomass, particularly in Mediterranean systems (Shakesby, 2011). The WorldView Soil Index contribution to the model of bare soil must be highlighted. Due to the lack of a shortwave infrared (SWIR) band in the sensor on-board WorldView-2 satellite, the difference in reflectivity between the green and yellow region of the spectrum allows this index to detect the bare soil signal (DigitalGlobe, 2010). Whelan (1995) pointed out that the dead plant material (necromass) presents high flammability and, thus, its removal from the previously burnt area must be a post-fire management priority. We identified a high correlation of dead plant material with the Burnt Area Index due to the high charcoal content of these materials and the ability of this index to detect its signal (Chuvieco et al., 2002).

It should be noted that first and second order textures were particularly relevant in all post-fire recovery models because of the great spatial variation of the vegetation structure in the study area. Gómez et al. (2011) and Pu and Cheng (2015) highlighted that the textures derived from the visible region of the spectrum offer a better model performance than those calculated from the red edge and near-infrared region to predict parameters such as vegetation cover or vegetation height. However, several textures from both regions have offered a similar performance in the present study.

The use of active sensors such as LiDAR together with optical satellite imagery could improve the estimation of forest structural parameters over ecosystems with complex vegetation vertical structure (Clawges et al., 2008). However, in a full stand replacing post-fire environment with heterogeneous horizontal vegetation structure, high spatial resolution satellite imagery alone has proven to be in this study a useful tool in the estimation of post-fire vegetation structure. Moreover, LiDAR data are not widely accessible for land managers as opposed to satellite imagery (Wood et al., 2012) and their costs could be significantly higher (Donoghue and Watt, 2006; Petrou et al., 2015; Fassnacht et al., 2016).

\section{Conclusions}

1. The highest recovery of the Pinus pinaster population occurred in the low fire recurrence scenario, while the understory community exhibited a greatest recovery under high fire recurrence. Fire severity was only related to the Pinus pinaster population recovery, exhibiting an inverse relationship.

2. The spatial resolution of the WorldView-2 multispectral imagery was appropriate for the quantitative analysis of the post-fire vegetation structure in fire-prone Mediterranean ecosystems dominated by Pinus pinaster.

3. At the Pinus pinaster population level, the number and cover of seedlings were the best-modeled recovery structure variables. However, Pinus pinaster population structure models require a seedling abundance large enough in the field plots to contribute at a large extent to the overall plot reflectance. For the understory commu- nity, the woody species cover model presented the best predictive capacity.

4. Prediction models of post-fire vegetation recovery had the same performance in general terms both for the entire study framework and for each recurrence-severity scenario.

5. The combination of spectral indices, together with first or second order textures, or textures alone as predictors, provided the best results in all recovery models. Image texture from visible and infrared region of the spectrum offered a similar performance in this study.

6. The approach proposed in the present study could represent a fundamental tool for planning post-fire restoration actions given its potential to identify areas where external intervention could be necessary to promote the recovery of provisioning and regulating ecosystem services supply.

\section{Uncited references}

Fernández-Manso et al. (2015), San-Miguel-Ayanz and Camiá (2009).

\section{Acknowledgments}

This study was financially supported by the Spanish Ministry of Economy and Competitiveness, and the European Regional Development Fund (ERDF), in the framework of the GESFIRE (AGL2013-48189-C2-1-R) and FIRESEVES (AGL2017-86075-C2-1-R) projects; and by the Regional Government of Castilla and León in the framework of the FIRECYL (LE033U14) and SEFIRECYL (LE001P17) projects. J.M. Fernández-Guisuraga is supported by a predoctoral fellowship from the Spanish Ministry of Education (FPU16/03070).

\section{Appendix A. Supplementary material}

Supplementary data to this article can be found online at https:// doi.org/10.1016/j.foreco.2019.05.028.

\section{References}

Adler-Golden, S.M., Matthew, M.W., Bernstein, L.S., Levine, R.Y., Berk, A., Richtsmeier, S.C., Acharya, P.K., Anderson, G.P., Felde, G., Gardner, J., Hike, M., Jeong, L.S., Pukall, B., Mello, J., Ratkowski, A., Burke, H.H., 1999. Atmospheric correction for shortwave spectral imagery based on MODTRAN4. SPIE Proc. 3753, 61-69.

Álvarez, A., Gracia, M., Vayreda, J., Retana, J., 2012. Patterns of fuel types and crown fire potential in Pinus halepensis forest in the Western Mediterranean Basin. For. Ecol. Manage. 270, 282-290.

Alvarez, R., Valbuena, L., Calvo, L., 2007. Effect of high temperatures on seed germination and seedling survival in three pine species (Pinus pinaster, P. sylvestris and P. nigra). Int. J. Wildland Fire 16, 63-70.

Bannari, A., Asalhi, H., Teillet, P., 2002. Transformed Difference Vegetation Index (TDVI) for Vegetation Cover Mapping. Proceedings of the Geoscience and Remote Sensing Symposium.

Barry, K.M., Stone, C., Mohammed, C.L., 2008. Crown-scale evaluation of spectral indices for defoliated and discoloured eucalypts. Int. J. Remote Sens. 29 (1), 47-69.

Bastin, J.F., Barbier, N., Couteron, P., Adams, B., Shapiro, A., Bogaert, J., De Cannière, C., 2014. Aboveground biomass mapping of African forest mosaics using canopy texture analysis: toward a regional approach. Ecol. Appl. 24, 1984-2001.

Beaty, R.M., Taylor, A.H., 2001. Spatial and temporal variation of fire regimes in a mixed conifer forest landscape, Southern Cascades, California, USA. J. Biogeogr. 28 (8), 955-966.

Berk, A., Anderson, G.P., Bernstein, L.S., Acharya, P.K., Dothe, H., Matthew, M.W., Adler-Golden, S.M., Chetwyn, J.H., Richtsmeier, S.C., Pukall, B., Allred, C.L., Jeong, L.S., Hoke, M.L., 1999. MODTRAN4 radiative transfer modeling for atmospheric correction. SPIE Proc. 3756, 348-353.

Boegh, E., Soegaard, H., Broge, N., Hasager, C., Jensen, N., Schelde, K., Thomsen, A., 2002 airborne multi-spectral data for quantifying leaf area index, nitrogen concentration and photosynthetic efficiency in agriculture. Remote Sens. Environ. 81, 179-193.

Calvo, L., Baeza, J., Marcos, E., Santana, V., Papanastasis, V.P., 2012. Post-Fire management of shrublands. Springer Science + Business Media B.V., Dordrecht, 293-319.

Calvo, L., Santalla, S., Valbuena, L., Marcos, E., Tárrega, R., Luis-Calabuig, E., 2008. Post-fire natural regeneration of a Pinus pinaster forest in NW Spain. Plan Ecol. 197, 81-90.

Calvo, L., Huerta, S., Marcos, E., Calvo-Fernández, J., Taboada, A., 2015. The role of prescribed fire in the provision of regulating ecosystem services of Spanish heathlands. Ecol. Quest. 21, 71-73. 
Calvo, L., Hernández, V., Valbuena, L., Taboada, A., 2016. Provenance and seed mass determine seed tolerance to high temperatures associated to forest fires in Pinus pinaster. Ann. Forest Sci. 73, 381-391.

Chen, J., 1996. Evaluation of vegetation indices and modified simple ratio for boreal applications. Canad. J. Remote Sens. 22, 229-242.

Chen, D., Stow, D.A., Gong, P., 2004. Examining the effect of spatial resolution and texture window size on classification accuracy: an urban environment case. Int. J. Remote Sens. 25, 1-16.

Chu, T., Guo, X., Takeda, K., 2016. Remote sensing approach to detect post-fire vegetation regrowth in Siberian boreal larch forest. Ecol. Ind. 62, 32-46.

Chuvieco, E., Pilar-Martin, M., Palacios, A., 2002. Assessment of different spectral indices in the red-near-infrared spectral domain for burned land discrimination. Int. J. Remote Sens. 23, 5103-5110.

Chuvieco, E., Aguado, I., Yebra, M., Nieto, H., Salas, J., Martín, M.P., Vilar, L., Martínez, J., Martín, S., Ibarra, P., de la Riva, J., Baeza, J., Rodríguez, F., Molina, J.R., Herrera, M.A., Zamora, R., 2010. Development of a framework for fire risk assessment using remote sensing and geographic information system technologies. Ecol. Model. 221 (1), 46-58.

Chuvieco, E., Kasischke, E.S., 2007. Remote sensing information for fire management and fire effects assessment. J. Geophys. Res. 112, G01S90.

Clawges, R., Vierling, K., Vierling, L., Rowell, E., 2008. The use of airborne lidar to assess avian species diversity, density, and occurrence in a pine/aspen forest. Remote Sens. Environ. 112, 2064-2073.

Clemente, R., Navarro-Cerrillo, R., Gitas, I., 2009. Monitoring post-fire regeneration in Mediterranean ecosystems by employing multitemporal satellite imagery. Int. J. Wildland Fire 18, 648-658.

R Core Team (2015). R: A language and environment for statistical computing. R Foundation for Statistical Computing, Vienna, Austria. URL https://www.R-project.org/.

Crippen, R., 1990. Calculating the vegetation index faster. Remote Sens. Environ. 34, $71-73$.

Cuevas-Gonzalez, M., Gerard, F., Baltzer, H., Riano, D., 2009. Analysing forest recovery after wildfire disturbance in boreal Siberia using remotely sensed vegetation indices. Glob. Change Biol. 15, 561-577.

Daughtry, C.S.T., Walthall, C.L., Kim, M.S., Colstoun, E.B., McMurtrey, J.E., 2000. Estimating corn leaf chlorophyll concentration from leaf and canopy reflectance. Rem. Sens. Environ. 74, 229-239.

Diaz-Delgado, R., Lloret, F., Pons, X., 2003. Influence of fire severity on plant regeneration through remote sensing imagery. Int. J. Remote Sens. 24, 1751-1763.

DigitalGlobe, 2010. <http://global.digitalglobe.com >, [Accessed in: 07-01-2016].

Donoghue, D.N.M., Watt, P.J., 2006. Using LiDAR to compare forest height estimates from IKONOS and Landsat ETM + data in Sitka spruce plantation forests. Int. J. Remote Sens. 27, 2161-2175.

Draper, N.R., Smith, H., 1998. Applied Regression Analysis. Wiley-Intersci. 736, pp.

Eckert, S., 2012. Improved forest biomass and carbon estimations using texture measures from WorldView-2 satellite data. Rem. Sens. 4, 810-829.

Elvidge, C.D., Chen, Z., 1995. Comparison of broad-band and narrow-band red and near-infrared vegetation indices. Remote Sens. Environ. 54 (1), 38-48.

Engler, R., Waser, L.T., Zimmermann, N.E., Schaub, M., Berdos, S., Ginzler, C., Psomas, A., 2013. Combining ensemble modeling and remote sensing for mapping individual tree species at high spatial resolution. For. Ecol. Manage. 310, 64-73.

Fassnacht, F.E., Latifi, H., Stereńczak, K., Modzelewska, A., Lefsky, M., Waser, L.T., Straub, C., Ghosh, A., 2016. Review of studies on tree species classification from remotely sensed data. Remote Sens. Environ. 186, 64-87.

Fernández-García, V., Quintano, C., Taboada, A., Marcos, E., Calvo, L., Fernández-Manso, A., 2018. Remote sensing applied to the study of fire regime attributes and their influence on post-fire greenness recovery in pine ecosystems. Rem. Sens. 10, 733.

Fernández-García, V., Santamarta, M., Fernández-Manso, A., Quintano, C., Marcos, E., Calvo, L., 2018. Burn severity metrics in fire-prone pine ecosystems along a climatic gradient using Landsat imagery. Remote Sens. Environ. 206, 205-217.

Fernández-García, V., Fulé, P.Z., Marcos, E., Calvo, L., 2019. The role of fire frequency and severity on the regeneration of Mediterranean serotinous pines under different environmental conditions. For. Ecol. Manage. 444, 59-68.

Fernández-Guisuraga, J.M., Calvo, L., Fernández-García, V., Marcos-Porras, E., Taboada, A., Suárez-Seoane, S., 2019. Efficiency of remote sensing tools for post-fire management along a climatic gradient. For. Ecol. Manage. 433, 553-562.

Fernández-Manso, A., Quintano, C., Roberts, D.A., 2016. Burn severity influence on post-fire vegetation cover resilience from landsat MESMA fraction images time series in Mediterranean forest ecosystems. Remote Sens. Environ. 184, 112-123.

Gamon, J., Surfus, J., 1999. Assessing leaf pigment content and activity with a reflectometer. New Phytol. 143, 105-117.

García-Morote, F.A., Martínez-García, E., Andrés-Abellán, M., Caballero, E.R., Miettinen, H., López-Serrano, F.R., 2017. Direct seeding of Pinus halepensis Mill. for recovery of burned semi-arid forests: implications for post-fire management for improving. Nat. Regener. For. 8, 353.

Gitelson, A., Merzlyak, M., 1998. Remote sensing of chlorophyll concentration in higher plant leaves. Adv. Space Res. 22, 689-692.

Gitelson, A., Kaufman, Y., Merzylak, M., 1996. Use of a green channel in remote sensing of global vegetation from EOS-MODIS. Remote Sens. Environ. 58, 289-298.

Gitelson, A., Merzlyak, M., Chivkunova, O., 2001. Optical properties and nondestructive estimation of anthocyanin content in plant leaves. Photochem. Photobiol. 71, 38-45.

Gitelson, A.A., Stark, R., Grits, U., Rundquist, D., Kaufman, Y., Derry, D., 2002. Vegetation and soil lines in visible spectral space: a concept and technique for remote estimation of vegetation fraction. Int. J. Remote Sens. 23, 2537-2562.

Gitelson, A., Zur, Y., Chivkunova, O., Merzlyak, M., 2002. Assessing carotenoid content in plant leaves with reflectance spectroscopy. Photochem. Photobiol. 75 (3), 272-281.

Gómez, C., Wulder, M.A., Montes, F., Delgado, J.A., 2011. Forest structural diversity characterization in Mediterranean pines of central Spain with QuickBird-2 imagery and canonical correlation analysis. Canad. J. Remote Sens. 37, 628-642.
Gonzalez, M., Augusto, L., Gallet-Budynek, A., Xue, J., Yauschew-Raguenes, N., Guyon, D., Trichet, P., Delerue, F., Niollet, S., Andreasson, F., Achat, D.L., Bakker, M.R., 2013. Contribution of understory species to total ecosystem aboveground and belowground biomass in temperate Pinus pinaster Ait. Forests. Forest Ecol. Manage. 289, 38-47.

González-De Vega, S., De las Heras, J., Moya, D., 2016. Resilience of Mediterranean terrestrial ecosystems and fire severity in semiarid areas: responses of Aleppo pine forests in the short, mid and long term. Sci. Total Environ. 573, 1171-1177.

Gu, Z., Ju, W., Li, L., Li, D., Liu, Y., Fan, W., 2013. Using vegetation indices and texture measures to estimate vegetation fractional coverage (VFC) of planted and natural forests in Nanjing city, China. Adv. Space Res. 51, 1186-1194.

Haboudane, D., Miller, J.R., Pattey, E., Zarco-Tejada, P.J., Strachan, I.B., 2004. Hyperspectral vegetation indices and novel algorithms for predicting green LAI of crop canopies: modeling and validation in the context of precision agriculture. Remote Sens. Environ. 90, 337-352.

Haralick, R.M., Shanmugam, K., Dinstein, I.H., 1973. Textural features for image classification. IEEE Transac. Syst., Man Cybern. 3 (6), 610-621.

Immitzer, M., Atzberger, C., Koukal, T., 2012. Tree species classification with random forest using very high spatial resolution 8-band WorldView-2 satellite data. Remote Sensing 4, 2661-2693.

Joyce, M.J., Erb, J.D., Sampson, B.A., Moen, R.A., 2019. Detection of coarse woody debris using airborne light detection and ranging (LiDAR). For. Ecol. Manage. 433, 678-689.

Jung, M., Tautenhahn, S., Wirth, C., Kattge, J., 2013. Estimating basal area of spruce and fir in post-fire residual stands in Central Siberia using quickbird, feature selection, and random forests. Procedia Comput. Sci. 18, 2386-2395.

Kaufman, Y., Tanre, D., 1992. Atmospherically resistant vegetation index (ARVI) for EOS-MODIS. IEEE Trans. Geosci. Remote Sens. 30, 261-270.

Kayitakire, F., Hamel, C., Defourny, P., 2006. Retrieving forest structure variables based on image texture analysis and IKONOS-2 imagery. Remote Sens. Environ. 102, $390-401$.

Key, C.H., 2006. Ecological and sampling constraints on defining landscape fire severity. Fire Ecol. 2, 34-59.

Key, C.H., Benson, N.C., 2006. Landscape assessment (LA) sampling and analysis methods. USDA Forest Serv. Gene. Tech. Rep.(RMRS-GTR-164-CD).

Lecina-Diaz, J., Alvarez, A., Retana, J., 2014. Extreme fire severity patterns in topographic, convective and wind-driven historical wildfires of mediterranean pine forests. PLoS ONE 9 (1), e85127.

Lee, D.W., Graham, R., 1986. Leaf optical properties of rainforest sun and extreme shade plants. Am. J. Bot. 73, 1100-1108.

Leone, V., Lovreglio, R., 2004. Conservation of Mediterranean pine woodlands: scenarios and legislative tools. Plant Ecol. 171, 221-235.

Leverkus, A.B., Rey Benayas, J.M., Castro, J., Boucher, D., Brewer, S., Collins, B.M., Donato, D., Fraver, S., Kishchuk, B.E., Lee, E.-J., Lindenmayer, D.B., Lingua, E., Macdonald, E., Marzano, R., Rhoades, C.C., Royo, A., Thorn, S., Wagenbrenner, J.W., Waldron, K., Wohlgemuth, T., Gustafsson, L., 2018. Salvage logging effects on regulating and supporting ecosystem services - a systematic map. Can. J. For. Res. 48, 983-1000.

Lozano, F.J., Suárez-Seoane, S., Kelly, M., Luis-Calabuig, E., 2008. A multi-scale approach for modeling fire occurrence probability using satellite data and classification trees: a case study in a mountainous Mediterranean region. Remote Sens. Environ. 112, 708-719.

Lozano, F.J., Suárez-Seoane, S., De Luis, E., 2010. Effects of wildfires on environmental variability: a comparative analysis using different spectral indices, patch metrics and thematic resolutions. Landscape Ecol. 25 (5), 697-710.

Lozano, F.J., Suárez-Seoane, S., de Luis-Calabuig, E., 2012. Does fire regime affect both temporal patterns and drivers of vegetation recovery in a resilient Mediterranean landscape? a remote sensing approach at two observation levels. Int. J. Wildland Fire 21 (6), 666-679.

Marchetti, M., Ricotta, C., Volpe, F., 1995. A qualitative approach to the mapping of post-fire regrowth in Mediterranean vegetation with Landsat TM data. Int. J. Remote Sens. 16, 2487-2494

Martin, T.G., Wintle, B.A., Rhodes, J.R., Kuhnert, P.M., Field, S.A., Low-Choy, S.J., Tyre, A.J., Possingham, H.P., 2005. Zero tolerance ecology: improving ecological inference by modelling the source of zero observations. Ecol. Lett. 8, 1235-1246.

Matthew, M., Adler-Golden, S., Berk, A., Felde, G., Anderson, G., Gorodetzky, D., Paswaters, S., Shippert, M., 2003. Atmospheric correction of spectral imagery: evaluation of the FLAASH algorithm with AVIRIS data. SPIE Proc. 5093, 474-482.

McCullagh, P., Nelder, J.A., 1989. Generalized Linear Models. In: Chapman and Hall. p. 532.

McFadden, D., 1974. Conditional Logit Analysis of Qualitative Choice Behavior. In: Zarembka, P. (Ed.), Frontiers in Economics. Academic Press, New York, pp. 105-142.

McKenna, P., Phinn, S., Erskine, P.D., 2018. Fire severity and vegetation recovery on mine site rehabilitation using WorldView-3 imagery. Fire 1, 22.

Meng, R., Wu, J., Zhao, F., Cook, B.D., Hanavan, R.P., Serbin, S.P., 2018. Measuring short-term post-fire forest recovery across a burn severity gradient in a mixed pine-oak forest using multi-sensor remote sensing techniques. Remote Sens. Environ. 210, 282-296.

Merzlyak, M., Gitelson, A., Chivkunova, O., Rakitin, V., 1999. Non-destructive optical detection of pigment changes during leaf senescence and fruit ripening. Physiol. Plant. 106 (1), 135-141.

Miller, J.D., Thode, A.E., 2007. Quantifying burn severity in a heterogeneous landscape with a relative version of the delta normalized burn ratio (dNBR). Remote Sens. Environ. 109, 66-80.

Moreira, F., Catry, F., Lopes, T., Bugalho, M.N., Rego, F., 2009. Comparing survival and size of resprouts and planted trees for post-fire forest restoration in central Portugal. Ecol. Eng. 35 (5), 870-873.

Moreira, F., Viedma, O., Arianoutsou, M., Curt, T., Koutsias, N., Rigolot, E., Barbati, A., Corona, P., Vaz, P., Xanthopoulos, G., Mouillot, F., Bilgili, E., 2011. Landscape-wild- 
fire interactions in southern Europe: implications for landscape management. J. Environ. Manage. 92 (10), 2389-2402.

Ni, N., Chen, N., Chen, J., Liu, M., 2015. Integrating WorldView-2 imagery and terrestrial LiDAR point clouds to extract dyke swarm geometry: implications for magma emplacement mechanisms. J. Volcanol. Geoth. Res. 310, 1-11.

Ozdemir, I., Karnieli, A., 2011. Predicting forest structural parameters using the image texture derived from WorldView-2 multispectral imagery in a dryland forest, Israel. Int. J. Appl. Earth Obs. Geoinf. 13, 701-710.

Pausas, J.G., Keeley, J.E., 2014. Abrupt climate-independent fire regime changes. Ecosystems $17,1109-1120$

Pausas, J.G., Vallejo, V.R., 1999. The role of fire in European Mediterranean Ecosystems. In: Chuvieco, E. (Ed.), Remote Sensing of Large Wildfires in the European Mediterranean Basin. Springer-Verlag, Berlin, pp. 3-16

Penuelas, J., Baret, F., Filella, I., 1995. Semi-empirical indices to assess carotenoids/ chlorophyll a ratio from leaf spectral reflectance. Photosynthetica 31 (2), 221-230.

Pesonen, A., Maltamo, M., Eerikäinen, K., Packalèn, P., 2008. Airborne laser scanning-based prediction of coarse woody debris volumes in a conservation area. For. Ecol. Manage. 255, 3288-3296.

Petrou, Z., Tarantino, C., Adamo, M., Blonda, P., Petrou, M., 2012. Estimation of vegetation height through satellite image texture analysis. Int. Arch. Photogram., Remote Sens. Spat. Inform. Sci. XXXIX-B8, 321-326.

Petrou, Z., Manakos, I., Stathaki, T., Mücher, C., Adamo, M., 2015. Discrimination of vegetation height categories with passive satellite sensor imagery using texture analysis. IEEE J. Sel. Top. Appl. Earth Obs. Remote Sens. 8, 1442-1455.

$\mathrm{Pu}, \mathrm{R}$., Cheng, J., 2015. Mapping forest leaf area index using reflectance and textural information derived from WorldView-2 imagery in a mixed natural forest area in Florida, US. Int. J. Appl. Earth Obs. Geoinf. 42, 11-23.

Quintano, C., Fernández-Manso, A., Shimabukuro, Y.E., Pereira, G., 2012. Spectral unmixing: a review. Int. J. Remote Sens. 33, 5307-5340.

Quintano, C., Fernández-Manso, A., Calvo, L., Marcos, E., Valbuena, L., 2015. Land surface temperature as potential indicator of burn severity in forest Mediterranean ecosystems. Int. J. Appl. Earth Obs. Geoinf. 36, 1-12.

Rautiainen, M., 2005. The spectral signature of coniferous forests: the role of stand structure and leaf area index. In: Doctoral Thesis. Universidad de Helsinki, Finlandia. p. 54.

Rondeaux, G., Steven, M., Baret, F., 1996. Optimization of soil-adjusted vegetation indices. Remote Sens. Environ. 55, 95-107.

Roujean, J., Breon, F., 1995. Estimating PAR absorbed by vegetation from bidirectional reflectance measurements. Remote Sens. Environ. 51, 375-384.

Rouse, J., Haas, R., Schell, J., Deering, D., 1973. Monitoring Vegetation Systems in the Great Plains with ERTS. Third ERTS Symposium.

Ruíz-Gallardo, J.R., Castaño, S., Calera, A., 2004. Application of remote sensing and GIS to locate priority intervention areas after wildland fires in Mediterranean systems: a case study from southeastern Spain. Int. J. Wildland Fire 13, 241-252.

Sagra, J., Ferrandis, P., Plaza-Álvarez, P.A., Lucas-Borja, M.E., González-Romero, J., Alfaro-Sánchez, R., De las Heras, J., Moya, D., 2018. Regeneration of Pinus pinaster Aiton after prescribed fires: response to burn timing and biogeographical seed provenance across a climatic gradient. Sci. Total Environ. 637, 1550-1558.

, . pp.

Santamaría, J.E., 2015. El pino Pinaster de la Sierra del Teleno: crecimiento, producción y selvicultura. In: Doctoral Thesis. Universidad de León, España. p. 156.

Schmeer, S.R., Kampf, S.K., MacDonald, L.H., Hewitt, J., Wilson, C., 2018. Empirical models of annual post-fire erosion on mulched and unmulched hillslopes. CATENA 163, 276-287.

Schoennagel, T., Smithwick, A.H., Turner, M.G., 2008. Landscape heterogeneity following large fires: insights from Yellowstone National Park, USA. Int. J. Wildland Fire 17, 742-753.

Shakesby, R.A., 2011. Post-wildfire soil erosion in the Mediterranean: review and future research directions. Earth Sci. Rev. 105, 71-100.

Slaton, M.R., Hunt Jr, E.R., Smith, W.K., 2001. Estimating near-infrared leaf reflectance from leaf structural characteristics. Am. J. Bot. 88 (2), 278-284.

Slesak, R.A., Schoenholtz, S.H., Evans, D., 2015. Hillslope erosion two and three years after wildfire, skyline salvage logging, and site preparation in southern Oregon, USA. For. Ecol. Manage. 342, 1-7.

Solans-Vila, J.P., Barbosa, P., 2010. Post-fire vegetation regrowth detection in the Deiva Marina region (Liguria-Italy) using Landsat TM and ETM + data. Ecol. Model. 221, 75-84.

Soliño, M., Yu, T., Alía, R., Auñón, F., Bravo-Oviedo, A., Chambel, M.R., de Miguel, J., Del Río, M., Justes, A., Martínez-Jauregui, M., Montero, G., Mutke, S., Ruiz-Peinado, R., García Del Barrio, J.M., 2018. Resin-tapped pine forests in Spain: ecological diversity and economic valuation. Sci. Total Environ. 625, 1146-1155.
Song, C., Dickinson, M.B., 2008. Extracting forest canopy structure from spatial information of high resolution optical imagery: tree crown size versus leaf area index. Int. J. Remote Sens. 29, 5605-5622.

Sripada, R.P., Heiniger, R.W., White, J.G., Meijer, A.D., 2006. Aerial color infrared photography for determining early in-season nitrogen requirements in corn. Agron. J. 98, 968-977.

Stephens, S.L., Burrows, N., Buyantuyev, A., Gray, R.W., Keane, R.E., Kubian, R., Liu, S.R., Seijo, F., Shu, L.F., Tolhurst, K.G., van Wagtendonk, J.W., 2014. Temperate and boreal forest mega-fires: characteristics and challenges. Front. Ecol. Environ. 12, 115-122.

Storey, A., Stow, D.A., O'Leary, J.F., 2016. Assessing postfire recovery of chamise chaparral using multi-temporal spectral vegetation index trajectories derived from Landsat imagery. Remote Sens. Environ. 183, 53-64.

Sullivan, A.L., Surawski, N.C., Crawford, D., Hurley, R.J., Volkova, L., Weston, C.J., Meyer, C.P., 2018. Effect of woody debris on the rate of spread of surface fires in forest fuels in a combustion wind tunnel. For. Ecol. Manage. 424, 236-245.

Taboada, A., Tárrega, R., Marcos, E., Valbuena, L., Suárez-Seoane, S., Calvo, L., 2017. Fire recurrence and emergency post-fire management influence seedling recruitment and growth by altering plant interactions in fire-prone ecosystems. For. Ecol. Manage. 402, 63-75.

Taboada, A., Fernández-García, V., Marcos, E., Calvo, L., 2018. Interactions between large high-severity fires and salvage logging on a short return interval reduce the regrowth of fire-prone serotinous forests. For. Ecol. Manage. 414, 54-63.

Tapias, R., Climent, J., Pardos, J.A., Gil, L., 2004. Life histories of Mediterranean pines. Plant Ecol. 171, 53-68.

Taye, Z.M., Martínez-Peña, F., Bonet, J.A., de Aragón, J.M., de-Miguel, S., 2016. Meteorological conditions and site characteristics driving edible mushroom production in Pinus pinaster forests of Central Spain. Fungal Ecol. 23, 30-41.

Tessler, N., Sapir, Y., Wittenberg, L., Greenbaum, N., 2016. Recovery of Mediterranean vegetation after recurrent forest fires: insight from the 2010 forest fire on Mount Carmel, Israel. Land Degrad. Dev. 27, 1424-1431.

Tucker, C., 1979. Red and photographic infrared linear combinations for monitoring vegetation. Remote Sens. Environ. 8, 127-150.

Van Drooge, B.L., Sicard, M., Stohl, A., Fontal, M., Bravo, N., Muñoz, A., Lange, D. Fernández, P., Grimalt, J.O., 2016. Detection and simulation of wildfire smoke impacting a Mediterranean urban atmosphere. Atmos. Pollut. Res. 7, 494-502.

Veraverbeke, S., Gitas, I., Katagis, T., Polychronaki, A., Somers, B., Goossens, R., 2012 Assessing post-fire vegetation recovery using red-near infrared vegetation indices: accounting for background and vegetation variability. ISPRS J. Photogramm. Remote Sens. 68, 28-39.

Ver-Hoef, J.M., Boveng, P.L., 2007. Quasi-poisson vs. negative binomial regression: how should we model overdispersed count data?. Ecology 88, 2766-2772.

Vermote, E.F., Saleous, N., Justice, C.O., Kaufman, Y.J., Privette, J.L., Remer, L., Roger, J.C., Tanre, D., 1997. Atmospheric correction of visible to middle-infrared EOS-MODIS data over land surfaces: background, operational algorithm and validation. J. Geophys. Res. 102, 17131-17141.

Viedma, O., Torres, I., Pérez, B., Moreno, J.M., 2012. Modeling plant species richness using reflectance and texture data derived from QuickBird in a recently burned area of Central Spain. Remote Sens. Environ. 119, 208-221.

Vieira, D.C.S., Malvar, M.C., Martins, M.A.S., Serpa, D., Keizer, J.J., 2018. Key factors controlling the post-fire hydrological and erosive response at micro-plot scale in a recently burned Mediterranean forest. Geomorphology 319, 161-173.

Whelan, R.J., 1995. The ecology of fire. Cambridge University Press, 346 pp.

Wolf, A., 2010. Using WorldView 2 Vis-NIR MSI Imagery to Support Land Mapping and Feature Extraction Using Normalized Difference Index Ratios. Unpublished report.

Wood, E.M., Pidgeon, A.M., Radeloff, V.C., Keuler, N.S., 2012. Image texture as a remotely sensed measure of vegetation structure. Remote Sens. Environ. 121, 516-526.

Yang, Z., Willis, P., Mueller, R., 2008. Impact of Band-Ratio Enhanced AWIFS Image to Crop Classification Accuracy. Proceedings of the Pecora 17 Remote Sensing Symposium.

Yue, Y.M., Wang, K.L., Zhang, B., Jiao, Q.J., Liu, B., Zhang, M.Y., 2012. Remote sensing of fractional cover of vegetation and exposed bedrock for karst rocky desertification assessment. Procedia Environ. Sci. 13, 847-853.

Zeileis, A., Kleiber, C., Jackman, S., 2008. Regression models for count data in R. J. Stat Softw. 27, 1-25.

Zhang, C., Xie, Z., 2012. Combining object-based texture measures with a neural network for vegetation mapping in the Everglades from hyperspectral imagery. Remote Sens. Environ. 124, 310-320.

Zuur, A.F., Ieno, E.N., Elphick, C.S., 2010. A protocol for data exploration to avoid common statistical problems. Methods Ecol. Evol. 1, 3-14. 